\title{
How behavioural research has informed consumer law : The many faces of behavioural research
}

\section{Nagatsu, Michiru}

Edward Edgar

2018-12-01

Nagatsu, M \& Malecka , M 2018 , How behavioural research has informed consumer law :

The many faces of behavioural research . in H-W Micklitz , A-L Sibony \& F Esposito (eds),

Research Methods in Consumer Law . Handbooks of research methods in law series,

pÿEdward Edgar , Cheltenham , pp. 357398 . https://doi.org/10.4337/9781785366611.00018

http://hdl.handle.net/10138/311300

https://doi.org/10.4337/9781785366611.00018

acceptedVersion

Downloaded from Helda, University of Helsinki institutional repository.

This is an electronic reprint of the original article.

This reprint may differ from the original in pagination and typographic detail.

Please cite the original version. 
Malecka, M. and Nagatsu, M. (2019) 'How behavioural research has informed consumer law: The many faces of behavioural research' in Hans-W. Micklitz, Anne-Lise Sibony, Fabrizio Esposito (eds.) Research handbook on methods in consumer law: A handbook. Edward Elgar Publishing. Earlier Draft: Please cite the published version.

Part I. The methodology of Consumer Law Scholarship: Conceptual issues

\title{
Chapter 1
}

\section{How behavioural research has informed consumer law: The many faces of behavioural research}

\author{
Michiru Nagatsu and Magdalena Małecka ${ }^{1}$
}

16 August 2017

$(14,564$ words including references)

\begin{abstract}
In this chapter we outline a history of various strands of behavioural research pertaining to consumer behaviour. We first look at the current field of consumer behaviour research qua a sub-discipline of marketing. This discussion reveals the multi-disciplinary nature of the field, which turns us next to the history of general trends in psychology that exert influences on many disciplines, and then to more specific developments in behavioural research at the intersection of economics and psychology. In the last section we review how these strands of behavioural research have been taken up by legal scholars at various points in history.
\end{abstract}

Keywords: history of behavioural sciences, consumer behaviour, multi- and interdisciplinarity, behavioural sciences and law, history of economics, history of psychology

\section{Introduction}

Consumer-related behavioural research has been an important drive in the recent developments in law towards more science-based legal scholarship and policy making. In particular, the movement called 'law and the behavioural sciences' has been directly influenced by the rise of behavioural economics, and indirectly by psychology that influenced behavioural economics. The body of research on consumption, however, is far wider than this strand of research. Broadly defined, consumer research is scattered across disciplines such as economics, psychology, sociology, anthropology, to name a few key disciplines, as well as marketing and business research conducted primarily in business schools. This makes a task of writing a comprehensive history of applied behavioural research on consumers beyond the scope of this chapter. But there is

\footnotetext{
${ }^{1}$ Both authors contributed equally.
} 
Malecka, M. and Nagatsu, M. (2019) 'How behavioural research has informed consumer law: The many faces of behavioural research' in Hans-W. Micklitz, Anne-Lise Sibony, Fabrizio Esposito (eds.) Research handbook on methods in consumer law: A handbook. Edward Elgar Publishing. Earlier Draft: Please cite the published version.

another, more pertinent reason why we do not focus on consumer behaviour as such. It is the fact that movements such as behavioural economics and 'law and behavioral sciences' have roots in the developments of a much more general study on human (and animal) behaviour. If we want to understand these roots, our historical focus should be on behavioural research in general rather than on consumer behaviour research. Furthermore, the behavioural research that entered consumer law was coming from the general behavioural sciences. For this reason, our narrative revolves around (a) the developments of general trends in psychology in the last 100 years and (b) how these trends influenced behavioural research at the intersection of economics and psychology.

To motivate our approach, however, we will first provide a snapshot of the field of consumer behaviour research (Section 2). This discussion will confirm that consumer behaviour research itself is to a large extent a product of the general developments in psychology and behavioural research that we will discuss (in Sections 3 and 4, respectively), although consumer behavior researchers tend to emphasize its disciplinary independence and uniqueness. Section 5 finally discusses how legal scholarship was affected by these trends identified in the previous sections. Section 6 concludes by briefly summarizing our findings, which overall suggest that it was the mixture of long-term general theoretical changes in behavioural research, inventions of formal decision and game theory, and the redrawing of the boundaries of psychology and economics to adapt to these changes, that influenced both consumer behaviour research and consumer law. The former's direct impact on the latter has been limited.

\section{Consumer behaviour research as a sub-discipline of marketing: A snapshot}

In this section we will delineate the field of contemporary consumer behaviour research, before discussing the developments in behavioural research more generally. It turns out however that this task is far from trivial. Practitioners in the field themselves have long been grappling with the questions of their disciplinary identity and status (e.g., Simonson et al. 2001). Although evaluating this rather internal debate among practitioners is not our goal here, it will be useful to have an overview of the current field, which is the product of the historical developments we will review later. An important message emerging from this overview is that the intellectual landscape of contemporary consumer behaviour research is by and large the product of the general developments in behavioural research we will discuss in Sections 3 and 4, except the interpretive approach, which we will briefly discuss in 2.3. This motivates our subsequent focus on psychology and economics, the two disciplines whose substantial interactions shaped the development of behavioural research in general, and of consumer behaviour research in particular. To see this, we mainly draw on Macinnis and Folkes (2010), who argue for three mostly empirical but also implicitly normative 
Malecka, M. and Nagatsu, M. (2019) 'How behavioural research has informed consumer law: The many faces of behavioural research' in Hans-W. Micklitz, Anne-Lise Sibony, Fabrizio Esposito (eds.) Research handbook on methods in consumer law: A handbook. Edward Elgar Publishing. Earlier Draft: Please cite the published version.

claims about (i) the disciplinary identity, (ii) the extension of the target domain of study, and (iii) the multidisciplinary nature of consumer behaviour research. We will discuss them in turn.

\subsection{Identity}

Concerning the identity of consumer behaviour research, Macinnis and Folkes (2010) claim that it is a sub-discipline of marketing. This means that institutionally speaking, much of consumer behaviour research takes place as part of the marketing discipline. One may wonder why this fact is worth establishing. The sub-disciplinarity of marketing, it turns out, refers to an attempt and (perceived) failure for consumer behaviour researchers to establish their own discipline with distinctive normative and theoretical orientations.

The commissioned studies on education in business schools in the late 1950s pointed out a need for more theoretical, research-based business education, to which business schools responded by hiring more research-oriented academics. Some of these new breeds focused on consumer behaviour as an object of research, and sought for institutional independence from marketing by founding the Association for Consumer Research (1969), publishing textbooks (e.g. Engel et al. 1968; Kassarjian \& Robertson 1968) and launching the flagship Journal of Consumer Research in 1974; their wish to distance themselves from marketing was also motivated by general concerns about potential negative societal impacts of advertizing and marketing of big businesses in the late 1960s. Despite this wish, much of consumer behaviour research nowadays takes place within marketing departments and business schools.

Note that the sub-disciplinarity is not a problem of being a minority in one's discipline. In fact, "almost a third of faculty in leading marketing departments describe themselves as consumer behaviour researchers" (Macinnis and Folkes 2010: 902), and "consumer researchers account for close to half of all (business school) marketing faculty" (Simonson et al. 2001: 250). Rather, the sub-disciplinarity suggests an academic identity crisis: on the one hand, consumer behaviour researchers have aspirations to make original theoretical contributions to the body of scientific knowledge and to be independent from business interests; on the other, institutionally speaking they find themselves 'trapped' in this business and marketing discipline, whose predominant perceived functions are to serve pedagogically and practically the profit maximization of the businesses. Macinnis and Folke's (2010) way out of this dissonance is to adopt "an elevated view of marketing", according to which marketing interacts with other actors such as consumers and policy makers in a wider societal context, explicitly incorporating the interests of these actors, e.g., in preventing negative effects of consumerism. Their role-model discipline here is accounting, which has achieved such an elevated status.

Regardless of the success of this intellectual identity management strategy, the fact that consumer behaviour researchers are concerned with wider societal implications of their research is worth highlighting when considering how other fields 
Malecka, M. and Nagatsu, M. (2019) 'How behavioural research has informed consumer law: The many faces of behavioural research' in Hans-W. Micklitz, Anne-Lise Sibony, Fabrizio Esposito (eds.) Research handbook on methods in consumer law: A handbook. Edward Elgar Publishing. Earlier Draft: Please cite the published version.

such as consumer law can be informed by consumer behaviour research. We will come back to this issue in Section 5.

\subsection{The boundary of consumer behaviour research}

Macinnis and Folke (2010: 904), highlighting the consumer context, clearly delineate the target of consumer behaviour research as "end users' acquisition and consumption of products, services [and disposal], and experiences acquired through an economic marketplace and factors that affect or are affected by these activities." This is contrasted with two other ways to define the target domain. The first is to include actors whose consumption does not take place through "an economic marketplace" narrowly conceived, e.g. patients who choose doctors or voters who elect political candidates, as the objects of study. The other alternative even more broadly include human behaviour in general, of which consumer behaviour is a special case. Macinnis and Folke (2010) reject these broader definitions of the target domain, by arguing that the narrower and clear focus on individual consumer behaviour has enabled the concentration of intellectual resources and contributed to the production of original knowledge that could benefit neighboring fields as well.

This discussion of the territorial boundaries of consumer behaviour research, which draws on the sociology of science, concerns not so much the disciplinary self-image and identity as the autonomous regulation and maintenance of the institutionally and intellectually distinct processes of knowledge production. In particular, Macinnis and Folke's (2010) rejection of the definition of the field as applied behavioural research guards against the implicitly held view that consumer behaviour research lacks distinctive and coherent theories and models that should be found in a proper scientific discipline. Some consumer behaviour researchers in fact point out the lack of theoretical coherence in their field: "[i]n the study of consumer behaviour, theoretical orientations have developed as disparate streams." (DiClemente and Hantula 2003: 590)

\subsection{Inter- or Multi-disciplinary?}

Macinnis and Folke (2010) characterize such disparate orientations in consumer behaviour research by saying that the field is not interdisciplinary but multidisciplinary in nature. In making this claim, they follow the standard distinction, according to which an interdisciplinary research process involves substantial knowledge integration, that is, creation of new theories and methods by combining resources from different disciplines, often in a problem-driven way (e.g. to address climate change or public health); in contrast, a multidisciplinary research process is regarded as somewhat epistemically shallower (e.g. Klein 1990). We do not want to endorse this way of distinguishing inter- and multi-disciplinarity, since it is heavily based on the intuition that knowledge integration (which itself is an unexplicated notion) is desirable and easily achievable, which is unsupported by studies of actual interdisciplinary scientific practices. Interestingly, Macinnis and Folke (2010), while apparently accepting the 
Malecka, M. and Nagatsu, M. (2019) 'How behavioural research has informed consumer law: The many faces of behavioural research' in Hans-W. Micklitz, Anne-Lise Sibony, Fabrizio Esposito (eds.) Research handbook on methods in consumer law: A handbook. Edward Elgar Publishing. Earlier Draft: Please cite the published version.

distinction, highlights positive aspects of consumer behaviour research being multidisciplinary. That is, they suggest that this sub-discipline of marketing is thriving because of its openness to influences from other adjoining disciplines, such as economics, psychology, sociology and anthropology, though these influences have not blended to produce a unified field. As these inconsistent uses of the terms show, it is misleading to try to evaluate a scientific field by superficially labeling it interdisciplinary or multidisciplinary, but the distinction is useful for our purposes to the extent that it highlights that consumer behaviour research contains distinct trends or camps reflecting influences from different disciplines. ${ }^{2}$

There are several ways to distinguish such trends or camps. The most abstract way is to distinguish two paradigms, one that emphasizes formal theory building based on objective measurement of different aspects of consumer behaviour aimed at precise predictions (so-called the 'positivist' paradigm); and one that takes seriously consumers' subjective experiences that often escape formal representations and quantitative measurement, such as Likert-scale responses in a survey (so-called the 'interpretivist' paradigm). ${ }^{3}$ In the positivist paradigm models of or hypotheses about consumer behaviour are formulated, empirically tested and their variables measured; in contrast, in the interpretivist paradigm consumer behaviour is contextualized in a more 'open-ended' manner with emphasis on subjective experiences that are not necessarily manifest in behavior (Miller 2003: 2-3). A prominent approach in this paradigm is Consumer Culture Theory, which studies the sociocultural, experiential, symbolic, and ideological aspects of consumption (Arnould and Thompson 2005). The interpretive paradigm is gaining more authority in business schools (Miller 2003: 3), since the heated paradigm-broadening debate in the 1980s within consumer behaviour research. This assessment is supported by the fact that the proportion of the interpretive research increased in the 1980s and represent roughly $20 \%$ of the published articles in JCR since 1990s (Simonson et al. 2001: 259). We will not discuss research conducted in this paradigm in more detail because this would take us too far from this chapter's main focus on behavioural (as opposed to experiential or phenomenological) research. However, this does not mean that valuable insights for consumer law cannot in principle be gleaned from the interpretivist paradigm. In fact, researchers working in this paradigm emphasize managerial and marketing relevance of their research (see Arnould and Thompson 2005: 870). If they are correct, one would expect some legal relevance as well.

One can distinguish different areas within the other, positivistic paradigm, which will be our main focus in this chapter. Macinnis and Folkes (2010: 910, figure 3) distinguish Behavioural Decision Theory (e.g. heuristics and biases; inter-temporal

\footnotetext{
${ }^{2}$ Our use of the term 'interdisciplinary' and 'multidisciplinary' in the rest of the chapter is therefore not intended to be evaluative in any sense. In fact, we use only the term 'interdisciplinary' to characterize research process or field that involve more than one discipline.

${ }^{3}$ Of course formulating this contrast as positivist vs. post-positivist is intellectually obsolete because philosophers of science have shown that no science operates in the way the original positivists had envisioned. We are using these terms for lack of better alternatives.
} 
Malecka, M. and Nagatsu, M. (2019) 'How behavioural research has informed consumer law: The many faces of behavioural research' in Hans-W. Micklitz, Anne-Lise Sibony, Fabrizio Esposito (eds.) Research handbook on methods in consumer law: A handbook. Edward Elgar Publishing. Earlier Draft: Please cite the published version.

choice; preference construction) and Information Processing (attitudes; emotions/mood; memory; conscious/subconscious processes). For our purposes, however, contrasting Behavioural Decision Theory and Information Processing is misleading because this suggests a wrong dichotomy between behavioural and cognitive approaches in psychology. As we will see in the next two sections, such a dichotomy does not reflect actual historical developments. Simonson et al. (2001) distinguish Behavioural Decision Theory and Social Cognition. This categorization excludes temporal discounting, which is important in the development of behavioural research and its influences on law. We will therefore alternatively identify three strands in psychological research, namely behavioural decision research, temporal discounting, and social psychology, corresponding approximately to risk preference, time preference and social preference in economics.

In this section, we provided a rough snapshot of the current consumer behaviour research. In sum, it is a sub-discipline of marketing that operates under multidisciplinary influences. Within the so-called positivist paradigm, we identified three strands of behavioural research that we will focus in Section 4. Before that, we will first provide the broader history of behavioural research, with the discussion on how the term 'behavioural' is characterized, how it differs from 'behaviourism', and how the so-called cognitive revolution has changed its connotation.

\section{Behavioural research pertaining to consumer behaviour: A historical overview}

At the most general level, the aim of behavioural research is to establish generalizations about the subject matter of human behaviour-how people behave and why. Obviously, such a characterisation is too general to be informative. Therefore, it is important to look at specific ways in which this aim has been and is being pursued within particular disciplines and research traditions. Over time, the views on how to study behaviour were changing with various ramifications. We will briefly reconstruct them below. In order to reconstruct the origins of current research agenda within the behavioural sciences, it is crucial first of all to understand the influence that behaviourism had on social and behavioural sciences throughout the 20th century, including the ways researchers opposed to it. It is also important not to conflate behaviourism with behavioural research or behavioural sciences. Our historical sketch of developments in psychology below is based on McWilliams (2015), Smith (2015), Graham (2015); of the studies of judgment and decision-making on Hogarth \& Goldstein (1997); of the "behavioural turn"4 in the social sciences on Berelson \& Steiner (1964); of the history of dual-system theory on Frankish and Evans (2009).

\footnotetext{
${ }^{4}$ Note that this "behavioural turn" is not the one caused by the integration of psychological insights in economics and later in economically-informed legal research.
} 
Malecka, M. and Nagatsu, M. (2019) 'How behavioural research has informed consumer law: The many faces of behavioural research' in Hans-W. Micklitz, Anne-Lise Sibony, Fabrizio Esposito (eds.) Research handbook on methods in consumer law: A handbook. Edward Elgar Publishing. Earlier Draft: Please cite the published version.

\subsection{Behaviourism}

Behaviourism is an approach in psychology that had been influential from the 1920s to 1950s. Behaviourism has its impact also on neighbouring disciplines, such as sociology (Harre 1998; Molm 1981; Ellwood 1930), economics (Dietrich and List 2012; Edwards 2016), and political science (Dahl 1961; Johns 2009).

Initiated by Russian psychologists, most notably Ivan Pavlov (1849-1936), it was then developed and advanced by US scholars - John Watson (1878-1958) and B.F. Skinner (1904-90), as well as by Edward Thorndike (1874-1949), E. C. Tolman (1886-1959), C. L. Hull (1884-52), and E. R. Guthrie (1886-1959). The aim of behaviourism was to study relationships between environment and its stimuli and behavioural (physiological and overt) responses to them. For John Watson the goal of psychology was the prediction and control of behaviour. In order to provide the analysis that could be a basis for predicting and controlling behaviours he adopted Pavlov's conditioning approach. This then further led to the renewal of interest "in the empiricist tradition that emphasized learning experiences as the foundation of knowledge, rather than rationalist view that emphasized the importance of innate characteristics" (McWilliams 2015: 413).

As Graham (2015) notes, behaviourism can be understood as a methodological, psychological, and philosophical doctrine: methodological behaviourism claims that psychology is the science of behaviour (and not the science of mind). According to psychological behaviourism "behaviour can be described and explained without making ultimate reference to mental events or to internal psychological processes. The sources of behaviour are external (in the environment), not internal (in the mind)" (Graham 2015). Philosophical behaviourism states that "in the course of theory development in psychology, if, somehow, mental terms or concepts are deployed in describing or explaining behaviour, then either (a) these terms or concepts should be eliminated and replaced by behavioural terms or (b) they can and should be translated or paraphrased into behavioural concepts" (Graham 2015).

In psychology elements of all three versions of behaviourism are present. The researchers working within the behaviourist research programme studied associative, reflexive, respondent, conditioning, as well as purposive, goal-directed behaviour- that led to the development of learning theories investigating the primary mechanisms of adaptation to environmental change by (mainly animal) organisms. In the 1960s B.F. Skinner advanced operant conditioning approach by analysing the functional relationships between environment, overt behaviours and their consequences. He rejected theories of learning and cognitive explanations of behaviour.

Despite the dominant position of behaviourism up to the 60s (especially in the US psychology), psychologists, mainly in Europe, were studying sensation, perception, memory, and problem-solving. Most of them, however, treated observable behaviours as the evidence for psychological processes, and the method and approach of psychology was positivistic, based on the belief in independent reality accessible to human knowing through empirical research (see: McWilliams 2015: 414). 
Malecka, M. and Nagatsu, M. (2019) 'How behavioural research has informed consumer law: The many faces of behavioural research' in Hans-W. Micklitz, Anne-Lise Sibony, Fabrizio Esposito (eds.) Research handbook on methods in consumer law: A handbook. Edward Elgar Publishing. Earlier Draft: Please cite the published version.

One can already identify the influence of psychology on marketing in the period of behaviourism. As Buckley points out, "[t]he notion of a psychology whose assumptions and techniques were as applicable in the marketplace as in the laboratory was part of the very fabric of behaviourism itself." (1982: 207). Famously, Watson, one of the founders of behaviourism, after having been forced to resign Johns Hopkins University for a divorce scandal in 1920, joined the J. Walter Thompson Advertising Company, and later became its vice-president, where "he participated in the development of market research techniques, experiments to determine brand appeal and habit-forming qualities of cigarettes, and developed various advertising campaigns." (ibid.)

\subsection{Cognitive revolution}

The critical reaction to behaviourism in psychology came in the 1960s, with the development of cognitive psychology. Psychologists working within this research programme adopted a model of mind based on the computer, inspired by information theory, computer modelling approach and the generative linguistics. They started studying pattern recognition, attention, categorization, memory, reasoning, decision-making, problem solving, and language as information-processing in the mind (see Gardner 1985; Baars 1986 for detail). In the early 1970s the field of studies on memory and on language began to intersect. Psychologists became aware of related developments in linguistics and AI, so researchers in the latter disciplines became aware of pertinent work in psychology. Thus evolved the interdisciplinary movement called 'cognitive science'. Cognitive scientists started to study mental representations. It was pointed out that in order to understand human behaviour, it is not enough to study how an individual's behaviour is reinforced by outside stimuli , but rather emphasis should be put on the way in which the environment or learning history is internally represented by the individual.

The computer models in the beginning of the development of cognitive psychology used complex symbols as representations that are processed in a procedural manner. Later on, in the 1980s, the connectionist models, that had a form of neural networks, consisting of densely interconnected nodes, were proposed. "From a historical viewpoint, there is an ironic aspect about the ascendancy of connectionist models. Such models return to the pure associationism that characterized behaviourism. While connectionist models hardly fit with all behaviourist dictums their representations are not restricted to stimuli and responses, and they routinely assume massively parallel processing" (Smith 2015: 107). The other major direction in cognitive psychology was to study the neural basis of cognition relying on the findings in neurobiology, as well as the use of heuristics in judgment and decision making (we are discussing the latter development in section 4.1 below). 
Malecka, M. and Nagatsu, M. (2019) 'How behavioural research has informed consumer law: The many faces of behavioural research' in Hans-W. Micklitz, Anne-Lise Sibony, Fabrizio Esposito (eds.) Research handbook on methods in consumer law: A handbook. Edward Elgar Publishing. Earlier Draft: Please cite the published version.

\subsection{The Idea of Behavioural Sciences}

In this chapter we use behavioural research and the behavioural sciences more or less interchangeably, but it should be noted that the connotations of "behavioural sciences" have also changed over time. The behavioural sciences, as that term was originally intended, in the 1950s, included sociology, anthropology, psychology, and the behavioural aspects of biology, economics, geography, law, psychiatry, and political science. The aim of this interdisciplinary movement was to establish a unifying theory of human behaviour that would explain the main mechanisms of people's behaviour (Miller 1955). Behavioural scientists were thus interested in wide-ranging topics such as motivation, perception, values and norms, learning, attitudes and opinion, personality, social organization, group practices, and social institutions. They collected original data on the direct behaviour of individuals and groups through the use of diverse empirical methods, such as experiments, surveys, questionnaires, and interviews (see: Berelson, Steiner (1964)).

Historians emphasize (see e.g.: Crowther-Heyck 2006; Erickson 2013) that the development of the behavioural sciences in the 1950s was triggered and influenced by changes in the funding scheme for the social sciences that was supposed to be reformed through new research programmes financed by several private foundations, the Social Science Research Council, and a range of military research agencies. Among foundations, the biggest support came from The Ford Foundation. The key event was the development of a program designated to study "individual behaviour and human relations" but it soon became known as the behavioural sciences program. In the 1950s, when the behavioural sciences entered the scene of scientific research in the social sciences they were understood as mathematical, behavioural-functional, problem-centred, and interdisciplinary (Crowther-Heyck 2006: 431). The behavioural-functional approach meant that an individual could be known by its behaviours that could be identified by their effects on the elements of the system to which he/she belongs. Behaviours were described as functions (in a mathematical sense) of each other.

At a later stage, during the 1970-80s, however, research in the behavioural sciences became more specialized and discipline-oriented with increasing methodological sophistication. The emphasis was put on the development of computer modelling and simulation, advancement of statistical techniques, and the elaboration of survey research. The rapid technological advances in computer technology and cybernetics led to the rise and development of cognitive psychology, the development mentioned in the section 3.2. above, that has become a leading discipline within the behavioural sciences until today.

Nowadays, behavioural sciences comprise of a vast area of empirical and theoretical approaches to studying behaviour. The results of these studies are usually generalized in a form of theoretical frameworks that organize data into conceptual schemes. In each area of behavioural research a plenty of theoretical frameworks of this kind have been proposed. For example, in the recent review of theoretical results in the 
Malecka, M. and Nagatsu, M. (2019) 'How behavioural research has informed consumer law: The many faces of behavioural research' in Hans-W. Micklitz, Anne-Lise Sibony, Fabrizio Esposito (eds.) Research handbook on methods in consumer law: A handbook. Edward Elgar Publishing. Earlier Draft: Please cite the published version.

studies on health behaviour (Glanz, Bishop 2010) eighty-two theories of behaviour and behaviour change have been identified (examples include: An Action Model of Consumption, Bagozzi (2000); Affective Events Theory, Weiss (1996); General Theory of Deviant behaviour, Kaplan (1972); Health behaviour Internalisation Model, Bellg (2003); Prospect Theory, Kahneman, Tversky (1979); Regulatory Fit Theory, Higgins (2000); Theory of Interpersonal behaviour Triandis (1977)).

However, it should be noted that one of the theories, the dual-process/system theory was supposed to provide a more overarching theoretical framework, in cognitive psychology, but also, more broadly, in behavioural sciences. In the next section we comment on the origins of the theory.

\subsection{The origin of dual-process/systems in psychology}

The dual-process/system theory ---roughly the thesis that mental processes take place in two contrastive fashions, such as automatic vs. deliberative, effortless vs. effortful---plays an important role in the contemporary policy and legal scholarship, informed by behavioural research. The modern history of dual-process theories concerns those that developed after the cognitive revolution in psychology, during the 1960s and 1970s (see 3.2 above). Curiously, the developments of the dual-process theory (in the fields of learning, reasoning, social cognition, and decision making) were taking place more or less independently from each other (Frankish and Evans 2009: 13).

The cognitive revolution had an effect on the studies of learning and of memory. During the dominance of behaviourism, the focus of researchers was put on studying learning. The processes studied in the many studies of classical and operant conditioning were slow and incremental. In result of the cognitive revolution researchers shifted focus from learning to memory. The studies led to distinguishing between short-term and long-term memory systems (Atkinson \& Shiffrin, 1968). The dual-system theories of learning (Reber 1993) and thinking (Nisbett and Wilson 1977, Wason and Evans 1975) had important impact on the field. The main factor for developing the dual-process theories of reasoning was the observation of non-logical biases in studying people's performance in deductive reasoning tasks (Evans 1977). Afterwards, the dual-process theories of social cognition developed. Social psychologists tried to explain the discrepancy between explicitly stated attitudes and actual social behaviour that was established in experimental research. The models developed in the 1980s dealt with persuasion and attitude change. The distinction between automatic and controlled processing has been developed into influential theory of automaticity in social judgement by John Bargh (Bargh 2006).

\section{Economics and Psychology: Three Lines of Development}


Malecka, M. and Nagatsu, M. (2019) 'How behavioural research has informed consumer law: The many faces of behavioural research' in Hans-W. Micklitz, Anne-Lise Sibony, Fabrizio Esposito (eds.) Research handbook on methods in consumer law: A handbook. Edward Elgar Publishing. Earlier Draft: Please cite the published version.

As we noted in the previous section, the history of the behavioural sciences involves multiple disciplines and their interactions, in particular between economics and psychology. In this section, we will outline three important developments, the first two of which result from more substantial interactions between economics and psychology than the last. The first development concerns behavioural decision research, which led to the rise of behavioural economics as it is known for many, mostly through the practitioners' systematic efforts to have impact outside academia (e.g. Amir et al. 2005; Thaler and Sunstein 2008), but also through recent scholarly historical work (e.g. Heukelom 2014; Sent 2004) $)^{5}$. The second development concerns intertemporal choice, which originates in operant psychology under the strong influence of behaviourism. The third development concerns social psychology that also joined the banner of behavioural economics, but more recently as an add-on tool for behavioural change.

\subsection{Behavioural Decision Research and Risky Choice}

Research on judgment and decision making that inspired much of the contemporary behavioural turn in public policy and law has its origins in the 1940s and 50s. Psychological research on decision making was rooted in economics and statistics and was conducted by psychologists whose interests originated in issues of psychophysics, psychological measurement, ${ }^{6}$ and mathematical modelling in psychology. However, before looking at this development, we will briefly summarize how consumer choice is understood in economics as a special case of economic decision making, and its historical background.

'Consumer choice theory,' which is usually outlined in one of the first chapters of standard microeconomics textbooks, stipulates that consumers have complete and transitive preferences over bundles of goods, and choose so as to satisfy such preferences under given budget constraints (Hands 2010: 633). Consumer behaviour in this sense can be represented as maximization of an ordinal utility function, analogous to firms' profit maximization. This highly idealized and stylized theory constitutes a fundamental building block of economic theorizing. The term 'consumer choice' however is slightly misleading, since the main function of the theory is not to predict or explain any particular consumers' choice of particular goods --- e.g. whether John will

\footnotetext{
${ }^{5}$ Sent (2004) calls what is now understood as behavioural economics as 'new behavioural economics', and contrasts it with 'old behavioural economics'. The former studies "deviations from the benchmark of rationality" (Sent 2004, p. 747), while the latter, represented by scholars such as Herbert Simon, Richard Cyert, James March, and George Katona, did not rely on the concept of a deviation from the norm of rationality, but instead "focused on discovering the empirical laws that described behavior correctly and as accurately as possible" (Sent 2004, p. 742). We do not discuss 'old behavioural economics' here because its rejection of optimization and equilibrium analysis limited its impact on what we know as behavioural economics today. It is interesting to note that in the 70s and 80 s legal scholars were referring to these two strands of research, without conceptualizing them as alternative approaches (see our review of the literature in Section 5.2).

${ }^{6}$ Psychophysics is a subfield of psychology which studies the relation between stimulus and sensation; measurement in psychology is a broader conceptual and methodological issue concerning the measurement of psychological variables including sensation, perception, cognition, emotion, and behavior. See Michell (1999).
} 
Malecka, M. and Nagatsu, M. (2019) 'How behavioural research has informed consumer law: The many faces of behavioural research' in Hans-W. Micklitz, Anne-Lise Sibony, Fabrizio Esposito (eds.) Research handbook on methods in consumer law: A handbook. Edward Elgar Publishing. Earlier Draft: Please cite the published version.

drink beer or wine at a bar after work this evening; the textbook reference to consumption of beer and wine, for example, is just a pedagogical instrument to facilitate students' formal grasp of complementary, substitutive and other relations between different goods. ${ }^{7}$ One of the main functions of consumer choice theory in economics is instead to provide an aggregate demand function, which, together with an aggregate supply function provided by the theory of firms, enables equilibrium analyses of prices and quantities, and comparative static evaluations of welfare implications of different economic policies. This does not necessarily mean that economists' notion of 'consumer choice' or consumer behaviour has no reference, or lacks empirical contents (see e.g. Blundell 1988). ${ }^{8}$ Rather, the notion of choice is embedded in the aggregate scale of analysis at which economic models are typically tested (see Ross 2014).

The theory of consumer choice was developed through what is called the ordinal revolution in economics. This development is often understood as an achievement of the separation of economics from psychology, under the general influence of behaviourism. The idea is that preference theory made it unnecessary to refer to the unobservable hedonistic notion of utility. However, as Hands (2010) points out, strict behaviourism envisaged by young Paul Samuelson (1938) was abandoned as a core philosophy of revealed preference theory (Samuelson 1948; 1950; see Hands 2010: 640-641). It is thus more accurate to say that the preference theory is not behaviouristic. The exact nature of the notion of preferences and utility in economics is still controversial, and is becoming even more so after the rise of behavioural economics (Guala 2017), but notice that preferences have never disappeared as theoretical constructs in economics. Although we said consumer choice theory is highly abstract and stylized, it is still a theory of choice based on preferences.

So consumer choice theory is not strictly behaviouristic, but it is admittedly austere in terms of mental constructs, which explains its limited direct applicability in psychological research. In this respect, the game changer was Expected Utility Theory developed by John von Neumann (1903-57) and Oskar Morgenstern (1902-77) in Games and Economic behaviour (1944/1947). Expected Utility Theory (EUT henceforth) was developed to model decision making under uncertainty about others' behaviour, but the theory is applicable to risky choices in general.

Before EUT, preferences in economics were modeled as ordinal, such that when Bob's preference ordering is

a (American Pale Ale) > b (Baltic Porter) > c (Classic Rauchbier)

\footnotetext{
${ }^{7}$ Roughly speaking, beer and wine are complementary goods if decreased consumption of one leads to decreased consumption of the other; they are substitutable if decreased consumption of one leads to increased consumption of the other.

${ }^{8}$ So we think that it is misleading, at least in this context, to say that economists holds an "epistemology of generalized characterizations," while psychologists follow an "epistemology of directly refutable claims" (Heukelom 2014:6).
} 
Malecka, M. and Nagatsu, M. (2019) 'How behavioural research has informed consumer law: The many faces of behavioural research' in Hans-W. Micklitz, Anne-Lise Sibony, Fabrizio Esposito (eds.) Research handbook on methods in consumer law: A handbook. Edward Elgar Publishing. Earlier Draft: Please cite the published version.

then there is no difference between representing this preference ordering in utility functions as

$\mathrm{U}(\mathrm{a})=1, \mathrm{U}(\mathrm{b})=1 / 2, \mathrm{U}(\mathrm{c})=0$, and

$\mathrm{U}(\mathrm{a})=1, \mathrm{U}(\mathrm{b})=1 / 10, \mathrm{U}(\mathrm{c})=0$

This is because both numerical assignments imply the same choice behaviour of Bob when he faces choice between these beer options. And economists saw this as satisfactory because this spared them from unfounded reference to different degrees of hedonistic satisfaction from consumption. The situation however changes with the introduction of uncertainty. When Bob's option includes a 'lottery' (or a prospect), ${ }^{9}$ which consists of a fifty-fifty chance of getting American Pale Ale or Classic Rauchbier, we can empirically observe Bob's choice between Baltic Porter for sure and this lottery, denoted as [a: $1 / 2 ; \mathrm{c}: 1 / 2$ ]. If Bob chooses Baltic Porter over the lottery or vice versa, we can vary the chance in a systematic fashion, until Bob is indifferent between the two, at a certain probability $\mathrm{p}^{*}$. If we assign 1 to the utility of a $(E U(a)=1)$, and 0 to the utility of $c(E U(c)=0)$ for notational convenience, then we can compute that $E U(b)=p^{*}$. That is,

$$
\operatorname{EU}(\mathrm{a})=1, \mathrm{EU}(\mathrm{b})=\mathrm{p}^{*}, \mathrm{EU}(\mathrm{c})=0
$$

Different values of $\mathrm{p}^{*}$ are in this way based on different empirical observations and derive different predictions; if $0<\mathrm{p}^{*}<1 / 2$ Bob is willing to take a relatively large risk of ending up with Classic Rauchbier to obtain his favourite American Pale Ale (he is risk seeking); if $\mathrm{p}^{*}=1 / 2$ he is risk neutral; and if $1 / 2>\mathrm{p}^{*}>1$, he is risk averse. The notion of utility here (Expected Utility) is cardinal, such that it can represent different attitudes toward risks manifested in choice behaviour. The idea of EU was proposed by the Dutch-Swiss mathematician Daniel Bernoulli (1700-82) in 1738 as a solution to the St. Petersburg's Paradox, ${ }^{10}$ hence the term "Bernoulli curves" of EU functions. The operationalization and axiomatization of the subjective versions of EUT were developed by the mathematician Leonard Savage (1917-71) in Savage (1954), whose precursors

\footnotetext{
${ }^{9} \mathrm{~A}$ 'lottery' is in general a convenient way to refer to an action whose outcome is not determined. So taking an action of leaving home without an umbrella is choosing a 'lottery' [getting wet: $p$; staying dry: $1-p]$ if these are the two relevant outcomes.

${ }^{10}$ St. Petersburg Paradox refers to a problem in the game called St. Petersburg game. The game is played by flipping a fair coin until it comes up tails; the prize is determined by the total number of flips, $\mathrm{n}$, such that the prize equals $\$ 2^{\mathrm{n}}$. Since the expected payoff of each possible consequence is $\$ 1$, and since there are an infinite number of them, this sum is an infinite number of dollars. So it seems rational for a gambler who wants to maximize dollar income to be willing to pay any finite sum of dollars to play this game. And yet most people are not. Hence the paradox. Bernoulli proposed to solve this problem by distinguishing subjective utility from monetary payoffs. See Martin (2014) for a philosophical discussion.
} 
Malecka, M. and Nagatsu, M. (2019) 'How behavioural research has informed consumer law: The many faces of behavioural research' in Hans-W. Micklitz, Anne-Lise Sibony, Fabrizio Esposito (eds.) Research handbook on methods in consumer law: A handbook. Edward Elgar Publishing. Earlier Draft: Please cite the published version.

are the Italian statistician Bruno de Finetti (1906-85), and the Cambridge philosopher Frank P. Ramsey (1903-30) ${ }^{11}$.

In retrospect, EUT was a crucial development in bringing economists and psychologists closer in studying decision making. On the one hand, it made economic theory of choice psychologically richer than ordinal preference theory in the sense that it explicitly introduced two latent constructs---subjective beliefs and risk preferences---while specifying conditions under which these could be measured objectively. With this the notion of utility has become respectable, and behaviourist influences in economics was overcome. On the other hand, EUT also provided psychologists with an enormously useful empirical model of judgement and decision making: EUT is a model with which subjective beliefs and risk preferences can be experimentally measured; a benchmark against which empirical deviations from the model can be detected; and a default model from which a variety of alternative utility models can be constructed (see Angner and Loewenstein 2012).

Regarding the measurement, EUT and its axiomatic approach influenced the behavioural sciences in general, and psychology in particular, where the field called mathematical psychology developed (Michell 1999). EUT also gave rise to philosophical discussions on rationality, followed by early attempts to test it experimentally (Preston and Baratta 1948; Mosteller and Nogee 1951; Davidson, Siegel and Suppes 1955).

The psychologist Ward Edwards (1927-2005) learned EUT at Harvard under the influence of the statistician Frederik Mosteller (1916-2006), and introduced it to psychologists as Behavioural Decision Theory, (Edwards 1954, 1961; Edwards et al., 1963), a rational model of individual probability judgment (subjective Bayesianism) and choice under risk. Edwards (1954) popularized BDT among psychologists interested in psychophysics, psychological measurement, and mathematical modelling, thereby initiating a fruitful exchange between economists and psychologists that followed suit. In particular, with the growing influence of cognitive psychology, psychologists came to propose and test models that were constructed to embody hypotheses about psychological processes underlying decision making. Edwards' students at Michigan, Sarah Lichtenstein (1933 to present), Paul Slovic (1938 to present), and Amos Tversky (1937-96) among others, played a key role in developing behavioural decision research into this direction. Lichtenstein and Slovic's demonstration of the phenomenon called preference reversals, ${ }^{12}(1971 ; 1973)$ and its replication by experimental economists (Grether and Plott 1979), have stimulated economists and psychologists to develop

\footnotetext{
${ }^{11}$ Kyburg and Smokler (1964) include English translation of De Finetti's seminal paper (originally published in French in 1937) as well as Ramsey's paper (originally written in 1926 and published posthumously in 1931).

${ }^{12}$ Preference reversals refer to a phenomenon in which an agent's implied preference over options are reversed when different preference elicitation procedures are used (e.g. rating, valuing in dollars, choosing, etc.). More broadly the term may refer to such reversals from other changes (e.g. changes in descriptions of the choice options).
} 
Malecka, M. and Nagatsu, M. (2019) 'How behavioural research has informed consumer law: The many faces of behavioural research' in Hans-W. Micklitz, Anne-Lise Sibony, Fabrizio Esposito (eds.) Research handbook on methods in consumer law: A handbook. Edward Elgar Publishing. Earlier Draft: Please cite the published version.

alternative models to EUT. ${ }^{13}$ In particular, Tversky's collaborations with Daniel Kahneman (1934 to present) produced influential Prospect Theory (1979; see also papers collected in Kahneman and Tversky 2000), which is a hybrid model in which a subjective 'editing' of options as losses and gains precede the utility evaluation phase. These studies entered into economics mainstream thanks in particular to Richard Thaler (1980) and his Anomalies column series in the Journal of Economic Perspectives (see Heukelom 2014).

\subsection{Operant Psychology and Intertemporal Choice}

Another important interdisciplinary development took place at the intersection of economics and psychology on the study of intertemporal choice with temporal discounting. Again, before looking at this development, we will briefly summarize the standard discounted utility model used in economics.

In economics intertemporal choice had been discussed for a long time, but it was Samuelson's seminal paper (1937) "A Note on Measurement of Utility" that first offered a formal model. In this paper, Samuelson specified an agent's intertemporal preferences over consumption profiles $\left(c_{t}, \ldots, c_{T}\right)$ from time period $t$ to $\mathrm{T}$ at time $\mathrm{t}$ as a utility function with the following form:

$\mathrm{U}^{\mathrm{t}}\left(\mathrm{c}_{\mathrm{t}}, \ldots, \mathrm{c}_{\mathrm{T}}\right)=\Sigma(\mathrm{k}=0->\mathrm{T}-\mathrm{t}) \mathrm{d}(\mathrm{k}) \mathrm{u}\left(\mathrm{c}_{\mathrm{t}+\mathrm{k}}\right)$

A substantial assumption here is that the agent prefers immediate over delayed consumption, other things being equal. To model such preferences, Samuelson adopted a time-additive utility framework, in which "[d] uring any specified period of time, the individual behaves so as to maximise the sum of all future utilities, they being reduced to comparable magnitudes by suitable time discounting" (p. 156). As a 'suitable time-discounting' function, Samuelson proposed an exponentially declining discount function in the form:

$d(t)=1 /(1+\varrho)^{t}$

where $\varrho>0$ is the agent's constant discount rate. Importantly, this exponential specification of the discount function is necessary for the agent's choices to be consistent across time.

An alternative to Samuelson's discount function was proposed by the economist Robert Strotz (1922-1994) in his 1956 paper, in which he proposed different discounting functions graphically and possibilities of intertemporal inconsistency in choice (for details see Grüne-Yanoff 2015: 680-681). However, the subsequent development in economics focused on the axiomatization of Samuelson's time-additive

\footnotetext{
${ }^{13}$ Their later work on risk (Fischoff et al. 1981) provides a general framework to answer the problem of acceptable risk: “How safe is safe enough?" This literature is relevant not only to consumer law but regulations in general.
} 
Malecka, M. and Nagatsu, M. (2019) 'How behavioural research has informed consumer law: The many faces of behavioural research' in Hans-W. Micklitz, Anne-Lise Sibony, Fabrizio Esposito (eds.) Research handbook on methods in consumer law: A handbook. Edward Elgar Publishing. Earlier Draft: Please cite the published version.

utility framework with exponential discounting, and did not consider the empirical plausibility of different discount functions in any systematic way.

The clinical psychiatrist turned into behavioural psychologist George Ainslie (1944-present) changed this situation, by linking psychological studies of intertemporal behaviour with the economic time-additive utility framework. In 1967, Ainslie joined the Pigeon Lab at Harvard, which was originally established by Skinner in 1948. Skinner was a leading figure in operant psychology, in which animal behaviour was studied in the stimuli-response paradigm. In this paradigm, the connection between stimuli and response were reinforced with rewards and punishments. Skinner's successor at the Pigeon Lab, Richard Herrnstein (1930-94) experimentally studied how pigeons distribute their choices among various alternatives, and proposed the matching law, which states that pigeons match the distribution of their choices to the distribution of the reinforcers (delays of delivery in this case) for those choices (Herrnstein 1961). Chung and Herrinstein (1967) effectively proposed a discounting function with the following form:

$\mathrm{d}(\mathrm{t})=1 / \mathrm{t}$

which is incompatible with exponential discounting. This psychological hypothesis was not directly bid against the standard exponential discounting model in economics, because of the institutional, conceptual, and methodological differences between operant psychology and economic theorizing (Grüne-Yanoff 2015: 690). Ainslie brought these disciplines closer by focusing on intertemporal preference reversals, an implication of non-exponential discounting, as a manifestation of motivational conflicts inside the agent $(1975 ; 1986 ; 1991 ; 1992)$. In his 1975 paper Ainslie used the term 'hyperbolic discounting' for the first time to refer to the abovementioned discounting function, preparing the later behavioural economic framework that would contrast exponential with hyperbolic discounting in intertemporal choice. Another key move by Ainslie was his abandonment of the traditional behaviourist approach to measuring the discounting factor directly as the relative frequencies of choice between smaller-sooner, and larger-later rewards. Instead, he inferred hyperbolic discounting from the observation of pigeon's pre-committing behaviour to control later impulsive behaviour (Grüne-Yanoff 2015: 693). This shift of focus from stimuli-response reinforcement to internal motivational mechanisms facilitated the application of hyperbolic discounting to economic studies of human intertemporal choices. As is the case with EUT, the economics-psychology interdisciplinary exchange in this case was facilitated by a psychologically richer but at the same time axiomatically formulated modelling framework.

Ainslie's synthesis met economists' favorable acceptance in the 1980s, due to three factors (Grüne-Yanoff 2015: 696-7): the general trend to see economic relevance in the psychological research on judgement and decision making (in particular deviations from the rationality postulates, see 4.1 above); the acceptance of evidence 
Malecka, M. and Nagatsu, M. (2019) 'How behavioural research has informed consumer law: The many faces of behavioural research' in Hans-W. Micklitz, Anne-Lise Sibony, Fabrizio Esposito (eds.) Research handbook on methods in consumer law: A handbook. Edward Elgar Publishing. Earlier Draft: Please cite the published version.

from animal studies; and personal discipline-bridging by interdisciplinary figures such as Drazen Prelec (1955-) and David Laibson (1966-) $)^{14}$. Although the subsequent attempts to empirically identify unique discounting function have generally failed (which Grüne-Yanoff calls the diversity of measurements disappointment), the sophistication of models of intertemporal choice ensued. Laibson (1997) proposed quasi-hyperbolic discounting (borrowing from Phelps and Pollak (1968)), which has the following discounting function:

$$
\begin{aligned}
& \mathrm{d}(\mathrm{t})=1 \quad \text { if } \mathrm{t}=0 \\
& \mathrm{~d}(\mathrm{t})=\beta /(1+\varrho)^{\mathrm{t}} \quad \text { if } \mathrm{t}>0
\end{aligned}
$$

This was an important generalization for economists because it showed the exponential discounting as a special case of this when $\beta=1$. Laibson (1997) also studied intra-personal conflicts using game-theoretic framework, in which multiple temporal selves sequentially choose strategies, yielding a whole-person's behaviour as a Nash equilibrium. ${ }^{15}$ This approach has become popular in economics, suggesting again that economists are not uncomfortable with modelling latent-processes, as long as they are formally tractable within a well-developed theoretical framework, such as utility theory and game theory. Psychologists today are no less concerned with a unifying framework, but their primary concern is to explain various anomalies to formal models of choice by identifying an underlying system of mental mechanisms, and to intervene on those mechanisms (see e.g. Ainslie 2016). Within contemporary consumer behaviour research both economic and psychological approaches to intertemporal discounting co-exists, under the banner 'operant behavioural economics' (see Foxall 2003; 2016 and other papers in these special issues).

\subsection{Social Psychology and Interactive Choice}

In social contexts, not only does the agent behave taking into account risks and temporal discounting, but she does so in response (and in anticipation) to reactions by others and herself, or more generally as a member of group(s) to which she belongs. While substantial interdisciplinary exchange between economics and psychology took place in the field of individual decision making (the behavioural decision research (4.1) and the temporal discounting (4.2) literatures above), such exchange is rather limited in the field of strategic decision making (which concerns choices whose consequences depend on what others choose, and vice versa). The most important discipline-bridging formal theory in this field is game theory, which Luce and Raiffa's (1957) influential

\footnotetext{
${ }^{14}$ Both Prelec and Laibson studied psychology with Herrnstein at Harvard and later became professors in economics. Grüne-Yanoff (2015) claims that their interdisciplinary backgrounds facilitated the exchange between economics and psychology.

${ }^{15}$ Typically, game theory studies strategic decision making, where the consequences of the decisions by more than one person are interdependent. In this case, game theory is applied to strategic situations between sub-personal agents, such as a self who wants to maximize short-term gain and a self who wants to maximize long-term gain.
} 
Malecka, M. and Nagatsu, M. (2019) 'How behavioural research has informed consumer law: The many faces of behavioural research' in Hans-W. Micklitz, Anne-Lise Sibony, Fabrizio Esposito (eds.) Research handbook on methods in consumer law: A handbook. Edward Elgar Publishing. Earlier Draft: Please cite the published version.

textbook popularized not only in social psychology but also in other fields. The history of social psychology however do not feature interactions with economics beyond this, except occasional critical comments to highlight its own disciplinary identity (e.g. Ross et al. 2010: 8). ${ }^{16}$ For example, a growing body of literature in economics on social preferences are rarely mentioned. ${ }^{17}$ Part of the explanation may be a contingent fact that game-theoretical studies by social psychologists were not welcomed by the National Institute of Health (NIH) at one point (Ross et al. 2010: 15). ${ }^{18}$ However, a more substantial reason is probably that social psychology deals with the kind of social behaviour that is mediated by complex interactions between subjective perceptions, thoughts and feelings, rather than more linear, consequentialist, and goal-oriented strategic interactions. Despite the relative independence from economics, social psychology exerts a strong influence on practical applications, including consumer behavioural change, and for this reason the field is worth discussing briefly here. The following discussion is mostly based on Ross et al. (2010). See also Jones (1985).

The sub-disciplinary identity of social psychology is anchored not only to the topics it studies, such as (i) intra-group and inter-group processes; (ii) attitudes, opinions, and beliefs; and (iii) social perception and self-perception (Ross et al. 2010), but also to the way these topics are studied: its relatively stable methodological stance is that the key to explaining complex social behaviour is to reveal the subjective meanings of stimuli, the environment, and her own responses to them for the agent. This stance explains the limited impact of behaviourism on social psychology when the former was influential in other areas of psychology during the 1920-50s. At the same time, in so far as its identity is maintained, social psychologists seem "eclectic and interdisciplinary, taking "useful" theories and methods from wherever they could be found" (Ross et al. 2010: 17). In fact, the cognitive revolution replaced the existing hydraulic models of needs, drives, and tension systems with information-processing models underpinned by the computer metaphor for mind, thus substantially changing the outlook of social psychology (Ross et al. 2010: 16).

Specifically, the influence of the cognitive revolution came through research on judgment and decision making. Ross et al. (2010:16) note that Tversky and Kahneman's work on heuristics and biases in judgement (Kahneman and Tversky 1972, 1973 : Tversky and Kahneman 1973, 1974) were "among the most frequently cited by social psychologists, and their indirect influence on the content and direction of our field was even greater than could be discerned from any citation index." Nisbett and Ross (1980), now the classic of social judgement, was a response to this impact. Kahneman and

\footnotetext{
${ }^{16}$ An important exception is an invention of the Dictator game by Kahneman, Knetsch, and Thaler (1986).

${ }^{17}$ This agnostic or hostile attitude may well be reciprocal. Economic models of social preferences are rarely informed by social psychology (Lisciandra mimeo), but important exceptions are Bacharach's model of team reasoning (Bacharach, Gold and Sugden 2006) and Bicchieri's (2006) model of norm-following behaviour.

${ }^{18}$ Ross says that "the conventional wisdom of the time [in the Reagan/Stockman era 1981-1985] was that research of the sort that some social psychologists were pursuing using game theory paradigm would not be funded" (email: 15 March 2017)
} 
Malecka, M. and Nagatsu, M. (2019) 'How behavioural research has informed consumer law: The many faces of behavioural research' in Hans-W. Micklitz, Anne-Lise Sibony, Fabrizio Esposito (eds.) Research handbook on methods in consumer law: A handbook. Edward Elgar Publishing. Earlier Draft: Please cite the published version.

Tversky's work on Prospect Theory (1979) and framing effects on decision making (1984) also had a significant impact, creating the literature at the intersection of cognitive and social psychology (see e.g. papers in Gilovich et al. 2002). More recently, social perception, social memory, and social information processing have been studied under the umbrella term social cognition (Fiske and Taylor 1984; 2008), making social psychology even more cognitive, and consequently less motivational. With the growing concern for internal processes, interests in changing behaviour decreased (Ross et al. 2010: 21). From this perspective, the recent rise of the dual-process theories can be understood as an attempt to synthesize studies on processes involving motivation and emotion on the one hand, and cognition on the other (see 3.4 above).

However, the most salient social and commercial appeal of social psychology has always been not its sophisticated knowledge of mental processes, but rather its simple message that seemingly unimportant modifications of situational factors such as framing and priming ${ }^{19}$ sometimes result in surprisingly large effects on beliefs, attitudes and behaviour in social contexts. The power of priming and framing to change behaviour was demonstrated using game-theoretical experimental paradigms (e.g. Liberman et al. 2004; Kay et al. 2004). Subtle signalling of social norms has also shown to change people's behaviour with environmental consequences (such as energy use and littering) in field experiments (Cialdini et al. 1990; Schultz et al. 2007; Goldstein et al. 2008). Robert Cialdini's work on social influences (Cialdini et al. 1975), in particular his seminal book entitled Influence (2007), originally published in 1984, is central to this literature, but its roots in social psychology go back to earlier studies of persuasion to change attitudes and beliefs (see e.g. Holvant et al. 1953).

The power of subtle interventions has been celebrated in the recent literature on behavioural public policy (e.g. Thaler and Sunstein 2008, in particular see chapter 3), but the other side of the message from social psychology is that policy or other behavioural interventions should be carefully crafted, taking into account processes, in particular how people interpret those interventions in terms of dissonance, self-perception, attribution, framing and so on. Social psychologists have documented a range of unintended consequences of seemingly straightforward policy interventions (Ross and Nisbett 1991), suggesting that the power of subtle interventions is not robust across time and places. In particular, how those interventions interact with more traditional tools such as regulative restrictions and monetary incentives remains to be explored more systematically. But social psychologists' contribution to "an impressive collection of potential tools for changing behaviour" (Ross et al. 2010: 41) is undeniable.

\footnotetext{
${ }^{19}$ Framing concerns the use of different descriptions of an identical decision problem. For example you can describe the same prisoner's dilemma as a problem Annie and Bob face individually, or a problem Annie and Bob face as a team. Priming concerns the use of some words, symbols, etc., which are not directly connected to the decision problem at hand. For example, a prior exposure to words such as 'teamwork' and 'collective' may make it more likely that Annie and Bob cooperate despite their conflicting interests.
} 
Malecka, M. and Nagatsu, M. (2019) 'How behavioural research has informed consumer law: The many faces of behavioural research' in Hans-W. Micklitz, Anne-Lise Sibony, Fabrizio Esposito (eds.) Research handbook on methods in consumer law: A handbook. Edward Elgar Publishing. Earlier Draft: Please cite the published version.

\section{The uptake of behavioural research in law}

In this section we review the references to behavioural research made by legal scholars who apply findings of the behavioural sciences for consumer protection, or regulation of consumer behaviour. We indicate the extent to which the trends within the behavioural sciences and consumer-related research were reflected in legal scholarship. Our review is divided into three periods. The early period includes works published in the 1950-60s, when the development of the social and behavioural sciences had started and the legal scholarship was reacting to the new approaches to studying behaviour proposed and advanced within these fields. The second period is the 1970-80s, the time of the emergence of the economic analysis of law and its critics from other social scientific disciplines. Economic analysis of law became influential within legal scholarship and set the stage for debates within contract and tort law, as well as offered new perspectives for the analysis of consumer behaviour and its legal implications. The third period, the contemporary one, has started in the 1990s and continues until now. It witnessed the development of the behavioural law and economics and of what we now call "behavioural approaches to law", "law and behavioural sciences", and "behaviourally informed regulation and policy".

We review the literature and discussion in each period as follows: first, we provide background information on the general trends within the legal scholarship in respect to attempts to apply the behavioural sciences to law; we then list and comment on the theoretical findings that inspired consumer law and their affinity to the research done within the behavioural sciences. We will also mention the role of the references to these theories by legal scholars working within the field of consumer law.

\subsection{Early period}

\section{General trends:}

In the legal scholarship in the 1950s and 60s we can observe the reaction to the so-called behavioural revolution in the social sciences. During this period the projects of scientific analysis of law and its impact, as well as of behaviour related to law continued to be developed. The rationale for applying findings from the behavioural sciences to law has been present in legal scholarship since the emergence of legal realism and sociological jurisprudence (represented by: Karl Llewellyn, Oliver W. Holmes, John Ch. Gray, Herman Oliphant, Jerome Frank, Roscoe Pound). It was related to the understanding of law as a means of social control and to a search for the efficient solutions to societal problems. Scientific findings were believed to provide insights into how to achieve the desired societal aims through enactment of legal rules. This period witnessed the development of 'law and behavioural sciences' programmes at US universities (Yale, Chicago, Pennsylvania, Columbia) (Katz 1959; Schwartz 1959; Kalven 
Malecka, M. and Nagatsu, M. (2019) 'How behavioural research has informed consumer law: The many faces of behavioural research' in Hans-W. Micklitz, Anne-Lise Sibony, Fabrizio Esposito (eds.) Research handbook on methods in consumer law: A handbook. Edward Elgar Publishing. Earlier Draft: Please cite the published version.

1958). The programmes introduced new teaching curricula on behavioural research on law, and aimed at conducting interdisciplinary research projects at the intersection of behavioural sciences and legal scholarship (see Schwartz 1959; Kalven 1958). This tendency was in line with the interdisciplinary spirit of the behavioural sciences in their initial phase of its development. The courses on the behavioural sciences taught to law students included psychiatry, anthropology, psychology, and sociology. It was analysed how law as an established system of social control supports or modifies human behaviour, as well as what type of assumptions about human behaviour underlie legal institutions, to what extent these assumptions constitute a model of man and society and whether they can be tested and changed - through law. The idea was also to study the actual operation of legal institutions. There was also a progressive and reformist approach to applying the behavioural sciences to law, conducted not only in the spirit of social engineering, that resulted in the textbook publication by Macaulay and Friedman (1969). This type of work "exploded during the late 60s and 70s" (Macaulay 1984: 151). The idea was to work out "an empirical picture of (...) legal system in action" (Macaulay 1984: 155), but at the same time to pay attention to topics of social interaction and social change, including racial relations and segregation.

During this period scientistic ideas, such as experimental jurisprudence (Beutel 1958), or jurimetrics (Leoveinger 1961/62), were spreading across legal sciences. Experimental jurisprudence was an idea of evaluating existing laws and the formulation of new laws on the basis of appropriate scientific knowledge that was already available and the gathering of such scientific knowledge where it did not already exist. It was supposed to be a "science of law based on a rigorous application of the scientific method [which] should be devoted to the study of the phenomena of law-making, the effect of law upon society and the efficiency of laws in accomplishing the purposes for which they came into existence" (Beutel 1958: 18). Jurimetrics was a proposal on how to use the then emerging advances in electronics and methods of data retrieval to determine evidence for the sake of legal proceedings. The idea was to be able to formulate legal predictions that would be "stated in probability terms, and resting upon the validity of the analytical and statistical techniques applied to underlying data" (Leoveinger 1961/62: 273).

However, during this period the applications of the behavioural sciences to consumer law were not widely discussed. The reason for this is most probably the fact that the consumer protection started to be a part of legal system only in the 60 s (in the US the Consumer Bill of Rights was enacted in 1962; in the UE - in the Treaty of Rome 1957 there was a general provision that the consumer should benefit from a deregulated, integrated and more efficient common market). We mention this period, nevertheless, in order make the reader aware of the context in which the behavioural research started to inform legal scholarship. Behavioural research, however, entered consumer law during a later period. 
Malecka, M. and Nagatsu, M. (2019) 'How behavioural research has informed consumer law: The many faces of behavioural research' in Hans-W. Micklitz, Anne-Lise Sibony, Fabrizio Esposito (eds.) Research handbook on methods in consumer law: A handbook. Edward Elgar Publishing. Earlier Draft: Please cite the published version.

\subsection{Mid-period (70s-80s)}

\section{General trends:}

As mentioned in the previous section, during the 1970s the studies of law and its operation within society accelerated (Macaulay 1984). At that time, the leading discipline of the behavioural sciences informing law was sociology. At the same time, the 1970s witnessed the development of economic analysis of law - the influential approach to studying law and its impact by applying theories of neoclassical economics to analyze people's responses to legal norms. The tensions between sociology and economics in studying law have been portrayed in (Symposium 1997). In the 1970s the advancements in decision theory and cognitive psychology, discussed by us in the section 4.1., started to have impact on legal debates. It is important to note here that during this period research in cognitive psychology was entering legal scholarship separately from the influences of neoclassical economics on law. The behavioural insights were especially influential in the area of consumer law, as we will mention below. During this time also the journal Law and Human Behaviour was founded in 1977 - an official journal of American Psychology-Law Society that was publishing empirical and theoretical works in criminal justice, law, psychology, sociology, psychiatry, political science on topics arising from the relationships between human behaviour and the law, the legal system, and the legal process.

\section{Consumer law and behavioural findings:}

The overview of the behavioural findings applied to consumer law during this period, which aims also at general characterization of the main trends, is given by Silber (1990). Silber divides consumer lawyers' responses to the behavioural findings into two approaches: those of neoformalists and of behaviouralists. Both groups responded differently to the increasing reliance on judgment and decision making research by courts. Neoformalists accepted the maximization of expected utility as a standard of rationality and thus claimed that "instead of encouraging freedom of contract and promoting economic efficiency, "psychologically-driven" standards rest on incomplete information about consumer behaviour and thereby tolerate, even promote, consumer unreasonableness, irrationality and ignorance" (Silber 1990: 69). The agenda of neoformalists, as Silber understood them, was then close to the views of (neoclassical) law and economics scholars. Behaviouralists, on the other hand, referred to research on framing effects, heuristics and biases and regret theory, induced disinclination to maximize utility under certain conditions, inaccurate probability estimates, and information overload, and argued that there is a need for redefining the notion of a reasonable consumer. It has been discussed when legal standards should account for consumers' cognitive limitations and when cognitive errors should be regulated, or under which conditions, rather, treated as an argument in court adjudication. As we could see the discussion on the application of the behavioural sciences to consumer law was framed in a very similar way to the recent debates initiated and inspired by the 
Malecka, M. and Nagatsu, M. (2019) 'How behavioural research has informed consumer law: The many faces of behavioural research' in Hans-W. Micklitz, Anne-Lise Sibony, Fabrizio Esposito (eds.) Research handbook on methods in consumer law: A handbook. Edward Elgar Publishing. Earlier Draft: Please cite the published version.

literature on nudging (see more on this in the point 5.3 below). The main influence on the take-up of the behavioural research by consumer lawyers was coming from the behavioural decision research we discussed in 4.1.

Several points are worth highlighting during this period: (1) consumer law was also informed by the empirical studies on consumer behaviour, which were less driven by theoretical advancements in behavioural decision research and more by the collection of data; (2) discussion in law was inspired not only by Tversky and Kahneman's research programme, but also by so-called "old behavioural economics"20; (3) there were attempts to propose behavioural models (alternative to Expected Utility Theory) that directly address consumer behaviour and were supposed to have implications for legal policy; and (4) the discussion concerned, similarly to contemporary debates, the possible irrelevance of biases at the market level and the possible difficulty with the idea of deviation from the norm of rationality and its implications for legal remedies in consumer law.

For instance, Mason \& Himes (1973) conducted empirical studies to develop behavioural and socio-economic profiles of consumer complaints, as a basis for industry and governmental intervention. Block (1974) provided a critical commentary on evidence on consumer behaviour, both observational and experimental (relating to job analyses in cases involving industrial accidents with machines; evidence concerning psychological studies of pilot performance, reaction time, and ability to respond to emergencies; evidence of the results of experiments dealing with the use of household products) and he commented upon how this evidence should be used by courts to choose an appropriate liability rule ${ }^{21}$.

Bernacchi (1978) advanced a behaviourally-oriented model for determining defective-product liability. He proposed expectation-performance-frustration model. It was based on the presumption that the decision process of any consumer is a function of many environmental characteristics which are product-, situation- and consumer-based, with the consumer decision process modelled as affected by the consumer's cognition, affect and conation. The author proposed that all distinctions between the compensability of economic loss and physical harm should be abolished and that recovery should be based on the fact of product failure rather than the form in which the failure is experienced. Bernacchi suggested that courts should adopt a modified version of strict liability in tort as the sole approach to recovery whenever defective products cause harm: courts should view a product as "defective" to the extent that it frustrates the reasonable expectations of the ordinary consumer.

Latin (1982) referred to the works of Miller (1956), Katona (1975), Morgan

\footnotetext{
${ }^{20}$ The "old" behavioural economists were dissatisfied with mainstream economics and had "a desire to develop an alternative using insights from (cognitive) psychology" (Sent 2004, p. 742). See footnote 5 above.

${ }^{21}$ Block claimed that the question of defectiveness of a product, that determines the choice of a liability rule, cannot be adequately determined without first examining the question of whether the product was dangerous for that use which the defendant was obliged for foresee and that this can be determined only by evidence as to how the consumer actually uses a particular product.
} 
Malecka, M. and Nagatsu, M. (2019) 'How behavioural research has informed consumer law: The many faces of behavioural research' in Hans-W. Micklitz, Anne-Lise Sibony, Fabrizio Esposito (eds.) Research handbook on methods in consumer law: A handbook. Edward Elgar Publishing. Earlier Draft: Please cite the published version.

(1978), Simon (1978) on limited capabilities to absorb, process and understand information, as well as on adopting simplified decisional criteria or "rules of thumb" to limit their expenditure of time and attention, in order to analyse decision-making in environmental markets. He claimed that this decision-making is inefficient because decentralized market actors ordinarily lack the environmental information necessary to make choices in line with their preferences. Therefore he argued that proposals for environmental deregulation should be regarded with great scepticism. Latin claimed that the way legal scholars and policy-makers are dealing with environmental consumption $^{22}$, should not be characterized as consumer sovereignty versus government paternalism and coercion. Rather, the question was for him whether environmental decision-making by collective representatives, together with whatever coercion is required to implement their decisions, will generally be preferable to the uninformed environmental market choices that consumers typically do and must make.

Schwartz and Wilde (1983) engaged with the works on judgment and decision making - on cognitive errors and overconfidence (e.g. Kahneman, Slovic, and Tversky (1982); Nisbett and Ross (1980)) and they questioned the claim that imperfect information leading to incorrect choice is pervasive. They argued that instead of focusing on representative individual consumers, each of whom may lack the data and skill to calculate risks perfectly, one should rather ask the question whether consumer error in assessing risks is biased in the aggregate. If consumers as a group err in evaluating the odds in ways that are either systematically pessimistic or unbiased, then firms will respond as if their choices were correct. Schwartz and Wilde noticed that much of the regulation of contract terms on informational grounds is devoted to improving contract quality by banning terms that supposedly result from imperfectly informed consumer choice. Yet, they argued, the presumed existence of imperfect information seldom supports bans of terms with which consumers are familiar. Thus, if consumers actually care about important contract terms, legislatures should facilitate comparison shopping for them and courts should ban only those trivial terms that seem unfair.

Eskridge (1984) analysed whether disclosures in the mortgage transactions in the US adequately protected consumers. He referred to the following research on psychology of decision making: Katona and Mueller (1954); Newman and Staelin (1972); Arndt (1972); Simon (1957); Janis and Mann (1977), Nisbett and Ross (1980), and Tversky and Kahneman (1974). Then he argued that the analysis of the mortgage transaction in light of psychological decision-making theory reveals that homebuyers are often imperfectly informed about mortgages and related costs, in part due to their own tendency not to shop and compare deals effectively, and in part due to the role of

\footnotetext{
${ }^{22}$ Latin understands environmental consumption as the consumption that "includes satisfactions derived from aesthetic and recreational experiences, from avoidance of pollution and its effects, from preservation of endangered species or undeveloped land, and from many other aspirations linked to environmental circumstances" (Latin 1984: 189).
} 
Malecka, M. and Nagatsu, M. (2019) 'How behavioural research has informed consumer law: The many faces of behavioural research' in Hans-W. Micklitz, Anne-Lise Sibony, Fabrizio Esposito (eds.) Research handbook on methods in consumer law: A handbook. Edward Elgar Publishing. Earlier Draft: Please cite the published version.

the sales process in influencing, and sometimes distorting, consumer choice. He proposed the following potential reforms, on the basis of his analysis: (1) better disclosure rules (requiring more accurate comparative information to be made during the shopping process); (2) standardization of mortgage instruments, including preformulated risk protections for alternative mortgage instruments; and (3) reduction in the distortions caused by the shopping process and anticompetitive patterns of cooperation within the real estate industry, both by assuring higher fiduciary standards for those who advise the homebuyer and by attacking these patterns of cooperation.

Finally, Scott (1985/6) claimed that the vast literature on human error and cognition ${ }^{23}$ was misunderstood by legal analysts working on consumer law. He pointed out that the "error" in human judgment and decision-making that the psychological literature posits is the deviation between empirically observed behaviour and some theoretical conception of ideal rationality. According to the author, knowing how human behaviour deviates from an idealized norm contributes valuable insights to our understanding of legal institutions. But he warned that the legal analyst must guard against the problematic assumption that inherently fallible behaviour is correctable through legal regulation. In terms of the problem of information overload, for instance, while more disclosure may not be dysfunctional, changes in the methods or forms of disclosure may well have unintended effects that reduce the benefits of intervention.

\subsection{Contemporary period (1990s - till now)}

\section{General trends:}

In the 1990s the increasingly influential application of the behavioural sciences to legal scholarship was taking place through behavioural economics that started to play an important role within the law and economics movement. The criticism of neoclassical economics made by behavioural economists inspired also critical revision of economic theories applied to law. Proponents of behavioural law and economics criticized the neoclassical approach for proposing highly idealized models of human behaviour which lack predictive power. Critique of that kind often had the form of criticizing rational choice theory or rationality assumptions for failures in predicting how people form judgement and make decisions. Behavioural law and economics scholars advocated observing, analyzing and explaining the "actual" behaviours of subjects (Jolls, Sunstein, and Thaler 1998). They emphasized that many deviations from predictions based on neoclassical models are systematic and can be explained on the basis of an alternative theory (of decision-making). Finally, proponents of this, 'new', behavioural approach held that their analyses of behaviour can and should be used by law and policy makers. They claimed that interventions into the sphere of people's decisions should be based on knowledge about possible behavioural responses to law. In other words, they advocated applying the findings of behavioural sciences to make more realistic policy

\footnotetext{
${ }^{23}$ He comments on works of Keown, Slovic, Lichtenstein (1983); Tversky, Kahneman (1981); Fischoff (1975); Kahneman, Tversky (1973); Kahneman, Tversky (1972); Phillips, Edwards (1966).
} 
Malecka, M. and Nagatsu, M. (2019) 'How behavioural research has informed consumer law: The many faces of behavioural research' in Hans-W. Micklitz, Anne-Lise Sibony, Fabrizio Esposito (eds.) Research handbook on methods in consumer law: A handbook. Edward Elgar Publishing. Earlier Draft: Please cite the published version.

recommendations; the neoclassical approach, in their view, has become less relevant for legal policy making (Korobkin and Ulen 2000: 1056). In this way, the tradition of cognitive psychology and judgment and decision making, has started to influence the legal scholarship, anew, through economics and discussion on its application to law. ${ }^{24}$

\section{Consumer law and behavioural findings:}

The development of behavioural economics had a significant impact on the discussion within consumer law. We are not going to review the state of the discussion here. Sibony and Hellinger (2015) include a list of main publications on the topics published during this period (Sibony, Hellinger 2015: 209-10, footnote 1).

It should be noted that the heated debate in this area in general was about the degree of protection, and paternalism that the legal policies should entail. Recommendations concerned various paternalistic regulations aimed at protecting consumers from the negative consequences of 'limits in rationality'. Examples of typically paternalistic regulations include the requirement of mandated benefit terms in insurance contracts (to deal with the complexities of the decision problems consumers face); usury laws, which protect people from potentially ruinous long-term consequences of entering into contracts; laws which heighten standards of industry's liability for consumer products (in response to consumers' limited ability to assess risk (see e.g. Latin 1994); and laws which impose certain safety standards on manufacturers or business judgment rules in corporate law (to deal with negative consequences of judging in hindsight).

Proposals of milder forms of paternalism, such as asymmetric paternalism (Camerer et al. 2003) and libertarian paternalism (Sunstein and Thaler 2003), led to the discussion on nudging, the new form of governing and regulating people's behaviour. Their supporters argue that theoretical findings of prospect theory and heuristics-and-biases research may be used by policy makers in order to "steer people's choices in welfare-promoting directions without eliminating freedom of choice" (Sunstein and Thaler 2003: 1159), as well as to create "large benefits for those who make errors, while imposing little or no harm on those who are fully rational" (Camerer et al. 2003: 1212).

The discussion on nudging prompted the analysis of whether standards and ways of informing consumers about the goods and services are appropriate (Ben-Shahar 2009; Bar-Gill and Ferrari 2010), the use of default rules (Smits 2010; Engel and Stark 2015), consumer standard contract forms (Becher 2007; Luth 2010), and withdrawal from the contract (Hoeppner 2014; Luzak 2014).

As our brief summary of the use of the behavioural findings in the legal scholarship shows, the main channel through which behavioural research was informing consumer law, was directly from the behavioural sciences. The influence of

\footnotetext{
${ }^{24}$ Some attempts to criticize law and economics approach by bringing insights from judgment and decision making have been made earlier. See e.g. Kehnan (1979) and his criticism of the Coase theorem in law and economics.
} 
Malecka, M. and Nagatsu, M. (2019) 'How behavioural research has informed consumer law: The many faces of behavioural research' in Hans-W. Micklitz, Anne-Lise Sibony, Fabrizio Esposito (eds.) Research handbook on methods in consumer law: A handbook. Edward Elgar Publishing. Earlier Draft: Please cite the published version.

consumer research, developed institutionally within the discipline of marketing, was much less significant (but see e.g. Eskridge's (1984) reference to Newman and Staelin (1972), and Arndt (1972)). Although consumer law also drew on the results of the experimental research on how consumers behave, in this research consumers were construed as subject to the same tendencies as agents of any other type are. What defined the research questions in experimental and theoretical research on consumers is a type of decisions (consumer choices), rather than a particular type of reasoning and decision-making processes (see Section 2.2 above). Two things should be noted here. First, during the 70s and 80s, after the birth of cognitive psychology, lawyers were referring not only to Tversky and Kahneman's line of research, but also to the research programme advanced by Simon. In the contemporary discussion, however, practitioners refer mainly to Tversky and Kahneman's work. This change can be explained by the fact that behavioural research has recently entered law through behavioural economics, which is largely a product of Tversky and Kahneman's research programme (Heukelom 2014). Second, and more generally, legal scholarship was inspired by only a few lines of research within behavioural research, mainly behavioural decision research. As our review of the main trends and approaches within behavioural research (Section 3) shows, this field is much richer and multifaceted. An important question, which cannot be addressed here, is what epistemic and non-epistemic factors contributed to the uptake of particular theories by legal scholars.

\section{Conclusion}

In this chapter, we have reviewed a history of behavioural research that has been applied to studies of consumer behaviour and that has been also informing legal scholarship and consumer law. We attempted to show the multiplicity of overlapping trends, research approaches and research programmes aimed at studying human behaviour in general, and consumer behaviour in particular, that developed in the last century and are being advanced until present. We looked at the current field of consumer behaviour research and its identity, territory, and multi-disciplinarity (Section 2). In order to understand the origins of different trends and camps in contemporary consumer behaviour research, we reviewed developments in the behavioural sciences in general (Section 3), and in economics and psychology in particular (Section 4). We have also reviewed, in some detail, how these trends were picked up by legal scholars working on consumer related topics at different times during the second half of the 20th century (Section 5).

In sum, the legal scholars, just like consumer behaviour researchers, were mostly influenced directly by contemporary basic behavioural research, and not so much by consumer behaviour research. Although this historical case alone is insufficient for any generalization, it is a concrete counterexample to the thesis that problem-oriented applied research rather than disciplinary basic research will bring about high impact scientific outcomes. In our case, it was the long-term shift in theoretical orientations in 
Malecka, M. and Nagatsu, M. (2019) 'How behavioural research has informed consumer law: The many faces of behavioural research' in Hans-W. Micklitz, Anne-Lise Sibony, Fabrizio Esposito (eds.) Research handbook on methods in consumer law: A handbook. Edward Elgar Publishing. Earlier Draft: Please cite the published version.

basic research (from behaviourism to cognitivism to dual-process/system framework), inventions of formal models in decision and game theory, and methodological adaptations to these changes at the boundaries of economics and psychology, that had impact on both consumer behaviour research and consumer law. This is not to discourage legal scholars from looking at consumer behaviour research more systematically for new insights and inspirations. Whether legal scholars will do so, and how it will affect legal studies, remain open questions.

\section{References}

Ainslie, George. 1975. "Specious Reward: A behavioural Theory of Impulsiveness and Impulse Control." Psychological Bulletin 82(4):463-96.

Ainslie, George. (2016). The Cardinal Anomalies that Led to behavioural Economics: Cognitive or Motivational? Managerial and Decision Economics, 37(4-5): 261-273. Amir, O., Ariely, D., Cooke, A., Dunning, D., Epley, N., Gneezy, U., Koszegi, B., Lichtenstein, D., Mazar, N., Mullainathan, S. and Prelec, D., (2005). Psychology, behavioural economics, and public policy. Marketing Letters, 16(3-4), pp.443-454.

Angner, Erik (mimeo) What preferences really are. Unpublished manuscript.

Angner, Erik, Loewenstein, George, 2012. behavioural economics. In: Mäki, U. (Ed.), Philosophy of Economics, Handbook of the Philosophy of Science, vol. 13. Elsevier, pp. 641-689.

Arndt, Johan. Consumer search behaviour: An exploratory study of decision processes among newly-married home-buyers. 1972.

Arnould, Eric J. and Craig J. Thompson (2005), “Consumer Culture Theory (CCT): Twenty Years of Research," Journal of Consumer Research, 31 (March), 868-82.

Atkinson, Richard C., and Richard M. Shiffrin. "Human memory: A proposed system and its control processes." Psychology of learning and motivation 2 (1968): 89-195.

Baars, B. J. (1986). The cognitive revolution in psychology. The Guilford Press.

Bacharach, M., Gold, N., \& Sugden, R. (2006). Beyond individual choice: teams and frames in game theory. Princeton: Princeton University Press.

Bagozzi, Richard P. "The poverty of economic explanations of consumption and an action theory alternative." Managerial and decision economics 21.3-4 (2000): 95-109.

Bar-Gill, Oren, and Franco Ferrari. "Informing Consumers about Themselves. 3 Erasmus L." (2010).

Baum WM. 2006. Understanding behaviourism: behaviour, Culture, and Evolution (2nd edn). Blackwell Publishing:Malden, MA.

Becher, Shmuel I. "behavioural science and consumer standard form contracts." La. L. Rev. 68 (2007): 117.

Bellg, Albert J. "Maintenance of health behaviour change in preventive cardiology: internalization and self-regulation of new behaviours." behaviour modification 27.1 (2003): 103-131. 
Malecka, M. and Nagatsu, M. (2019) 'How behavioural research has informed consumer law: The many faces of behavioural research' in Hans-W. Micklitz, Anne-Lise Sibony, Fabrizio Esposito (eds.) Research handbook on methods in consumer law: A handbook. Edward Elgar Publishing. Earlier Draft: Please cite the published version.

Ben-Shahar, Omri. "The Myth of the 'Opportunity to Read'in Contract law." European Review of Contract Law 5.1 (2009): 1-28.

Berelson, Bernard, and Gary A. Steiner. "Human behaviour: An inventory of scientific findings." (1964).

Bernacchi, Michael D. "A behavioural Model for Imposing Strict Liability in Tort: The Importance of Analyzing Product Performance in Relation to Consumer Expectation and Frustration." U. Cin. L. Rev. 47 (1978): 43.

Beutel, Frederick K. "Some Potentialities of Experimental Jurisprudence as a New Branch of Social Science." (1959): 492-502.

Bicchieri, Cristina, 2006. The Grammar of Society. Cambridge University Press, Cambridge, England.

Block, Joyanne E. "The aged consumer and the market place: A critical review." Marquette Business Review 18.2 (1974): 73-81.

Blundell, R. (1988). Consumer behaviour: Theory and Empirical Evidence--A Survey. The Economic Journal, 98(389), 16-65.

Buckley, Kerry W. 1982. The selling of a psychologist: John Broadus Watson and the application of behavioural techniques to advertising. Journal of the History of the behavioural Sciences 18: 207-221.

Camerer, Colin, et al. "Regulation for Conservatives: behavioural Economics and the Case for" Asymmetric Paternalism"." University of Pennsylvania law review 151.3 (2003): 1211-1254.

Chung, Shin-Ho and Richard, J. Herrnstein. 1967. "Choice and Delay of Reinforcement." Journal of the Experimental Analysis of behaviour 10:67-74.

Cialdini, R. B. (2007). Influence: The psychology of persuasion. New York: HarperCollins. Cialdini, R. B. (2009). We have to break up. Perspectives on psychological science, 4, 5-6. Cialdini, R. B., Reno, R. R., \& Kallgren, C. A. (1990). A focus theory of normative conduct: Recycling the concept of norms to reduce littering in public places. Journal of Personality and Social Psychology, 58, 1015-1026.

Cialdini, R. B., Vincent, J. E., Lewis. S. K., Catalan, J., Wheeler, D., \& Darby, B. L. (1975). Reciprocal concessions procedure for inducing compliance: The door-in-the-face technique. Journal of Personality and Social Psychology, 31, 206-215.

Crowther-Heyck, Hunter. "Patrons of the revolution: Ideals and institutions in postwar behavioural science." Isis 97.3 (2006): 420-446.

Dahl, Robert A. "The behavioural approach in political science: Epitaph for a monument to a successful protest." American Political Science Review 55.04 (1961): 763-772.

Davidson, D., Siegel, S., Suppes, P., 1955. Some Experiments and Related Theory on the Measurement of Utility and Subjective Probability. Technical Report Prepared for Office of Naval Research. Stanford University, Stanford.

DiClemente, D. F., \& Hantula, D. A. (2003). Applied behavioural economics and consumer choice. Journal of Economic Psychology, 24(5), 589-602. 
Malecka, M. and Nagatsu, M. (2019) 'How behavioural research has informed consumer law: The many faces of behavioural research' in Hans-W. Micklitz, Anne-Lise Sibony, Fabrizio Esposito (eds.) Research handbook on methods in consumer law: A handbook. Edward Elgar Publishing. Earlier Draft: Please cite the published version.

Dietrich, Franz, and Christian List. "Mentalism versus behaviourism in economics: a philosophy-of-science perspective." Economics and Philosophy 32.02 (2016): 249-281.

Edwards, W., 1954. The theory of decision making. Psychological Bulletin 41, 380-417. Edwards, W., 1961. behavioural decision theory. Annual Review of Psychology 12, 473-498.

Edwards, W., Lindman, H., Savage, L.J., 1963. Bayesian statistical inference for psychological research. Psychological Review 70, 193-242.

Edwards, José. "Behaviourism and Control in the History of Economics and Psychology." History of Political Economy 48.suppl 1 (2016): 170-197.

Ellwood, Charles A. "The uses and limitations of behaviourism in sociology." Publications of the American Sociological Society 24 (1930): 74-82.

Engel, James F., David T. Kollat, and Roger D. Blackwell (1968), Consumer behaviour, New York: Rinehart \& Winston.

Engel, Martin, and M. Phil Johanna Stark. "Buttons, boxes, ticks, and trust." European Perspectives on behavioural Law and Economics. Springer International Publishing, 2015. 107-123.

Erickson, Paul, et al. "How reason almost lost its mind: The strange career of Cold War rationality." University of Chicago Press, 2013.

Eskridge Jr, William N. "One Hundred Years of Ineptitude: The Need for Mortgage Rules Consonant with the Economic and Psychological Dynamics of the Home Sale and Loan Transaction." Virginia Law Review (1984): 1083-1218.

Evans, J. St BT. (1977) "Toward a statistical theory of reasoning." The Quarterly Journal of Experimental Psychology 29(4) : 621-635.

Farber, Daniel A. "Contract Law and Modern Economic Theory." Nw. UL Rev. 78 (1983): 303.

Fischoff, B. (1975) Hindsight $\neq$ Foresight: The Effect of Outcome Knowledge on Judgment Under Uncertainty. Journal of Experimental Psychology: Human Perception and Performance 1:288-299.

Fischoff, B., Lichtenstein, S., Slovic, P., Derby, S. L., and Keeney, R. (1981) Acceptable Risk. Cambridge: Cambridge University Press.

Fiske, S. T., \& Taylor, S. E. (1984). Social cognition. New York: Random House.

Fiske, S. T., \& Taylor, S. E. (2008). Social cognition: From brains to culture. Boston: McGraw-Hill.

Foxall, G. R. (2003). The behaviour analysis of consumer choice: An introduction to the special issue. Journal of Economic Psychology, 24(5), 581-588.

Foxall, Gordon R. (2016) Operant behavioural Economics, Managerial and Decision Economics 37(4-5):215-223

Frankish, Keith, and J. S. B. T. Evans. "The duality of mind: an historical perspective." In two minds: Dual processes and beyond (2009): 1-29.

Gardner, H. (1985). The mind's new science: a history of the cognitive revolution. Basic Books.

Gilovich, T., Griffin, D., \& Kahneman, D. (Eds.). (2002). Heuristics and biases: The psychology of intuitive judgment. New York: Cambridge University Press. 
Malecka, M. and Nagatsu, M. (2019) 'How behavioural research has informed consumer law: The many faces of behavioural research' in Hans-W. Micklitz, Anne-Lise Sibony, Fabrizio Esposito (eds.) Research handbook on methods in consumer law: A handbook. Edward Elgar Publishing. Earlier Draft: Please cite the published version.

Glanz, Karen, and Donald B. Bishop. "The role of behavioural science theory in development and implementation of public health interventions." Annual review of public health 31 (2010): 399-418.

Goldstein, William M., and Robin M. Hogarth. "Judgment and decision research: Some historical context." Research on judgment and decision making: Currents, connections, and controversies (1997): 3-65.

Goldstein, N. J., Cialdini, R. B., \& Griskevicius, V. (2008). A room with a viewpoint: Using social norms to motivate environmental conservation in hotels. Journal of Consumer Research, 35, 472-482.

Graham, George, "behaviourism", The Stanford Encyclopedia of Philosophy (Spring 2017 Edition), Edward N. Zalta (ed.), forthcoming URL = $<$ https://plato.stanford.edu/archives/spr2017/entries/behaviourism

Grüne-Yanoff, T. (2015). Models of Temporal Discounting 1937-2000: An Interdisciplinary Exchange between Economics and Psychology. Science in Context, 28(4), 675-713.

Guala, Francesco (2017). Preferences: neither behavioural nor mental. UNIMI Working Paper No. 5/2017.

Hands, D. Wade (2010) Economics, psychology and the history of consumer choice theory. Cambridge Journal of Economics 34 (4): 633-648.

Harre, Rom. behaviourism in the social sciences, 1998, doi:10.4324/9780415249126-R002-1. Routledge Encyclopedia of Philosophy, Taylor and Francis, https://www.rep.routledge.com/articles/thematic/behaviourism-in-the-social-sci ences/v-1

Helgeson, James G., John Mager, and E. Alan Kluge (1985), “Consumer Research: Some History, Trends and Thoughts," in Historical Perspectives on Consumer Research, Provo, UT: Association for Consumer Research, 155-59.

http://acrwebsite.org/volumes/12135/volumes/sv05/SV-05

Herrnstein, Richard J. 1961. "Relative and Absolute Strength of Response as a Function of Frequency of Reinforcement. Journal of the Experimental Analysis of behaviour 4(3):267-272.

Higgins, E. Tory. "Making a good decision: value from fit." American psychologist 55.11 (2000): 1217.

Hoeppner, Sven. "The unintended consequence of doorstep consumer protection: surprise, reciprocation, and consistency." European Journal of Law and Economics 38.2 (2014): 247-276.

Heukelom, F. (2014). behavioural economics: A history. Cambridge: Cambridge University Press.

Hovland, Carl I.; Janis, Irving L.; Kelley, Harold H. (1953) Communication and persuasion; psychological studies of opinion change.New Haven, CT, US: Yale University Press.

Janis, Irving L., and Leon Mann. Decision making: A psychological analysis of conflict, choice, and commitment. Free press, 1977.

Jolls, Christine, Cass R. Sunstein, and Richard Thaler. "A behavioural approach to law and economics." Stanford law review (1998): 1471-1550. 
Malecka, M. and Nagatsu, M. (2019) 'How behavioural research has informed consumer law: The many faces of behavioural research' in Hans-W. Micklitz, Anne-Lise Sibony, Fabrizio Esposito (eds.) Research handbook on methods in consumer law: A handbook. Edward Elgar Publishing. Earlier Draft: Please cite the published version.

Jones, E. E. (1985). Major developments in social psychology during the past five decades. In G. Lindzey and E. Aronson (eds.), Handbook of social psychology, vol 1, 47-108. New York: Random House.

Kahneman, D., Knetsch, J.L., Thaler, R.H., 1986. Fairness and the assumptions of economics. The Journal of Business 59 (4), S285-S300.

Kahneman, D., Slovic, P., Tversky, A., 1982. Judgment under Uncertainty: Heuristics and Biases. Cambridge University Press, Cambridge.

Kahneman, D., Tversky, A., 1979. Prospect theory: an analysis of decision under risk. Econometrica 47 (2), 263-292.

Kahneman, Daniel, and Amos Tversky. "Subjective probability: A judgment of representativeness." The concept of probability in psychological experiments. Springer Netherlands, 1972. 25-48.

Kahneman, D., Tversky, A., 2000. Choices, Values, and Frames. Russell Sage Foundation, New York.

Kahneman, Daniel, and Amos Tversky. "On the psychology of prediction, 80 Psychol." REV 237 (1973): 257.

Kalven Jr, Harry. "Some Comments on the Law and Behavorial Science Project at the University of Pennsylvania." J. Legal Educ. 11 (1958): 94.

Kaplan, Howard B. "Toward a general theory of psychosocial deviance: The case of aggressive behaviour." Social Science \& Medicine (1967) 6.5 (1972): 593-617.

Kassarjian, Harold H. and Thomas S. Robertson (1968), Perspectives in Consumer behaviour, Glenview, IL: Scott, Foresman.

Katona, George. Psychological economics. Elsevier, 1975.

Katona, George, and Eva Mueller. "A study of purchase decisions." Consumer behaviour: The dynamics of consumer reaction 1 (1955): 30-87.

Katz J., The law and behavioral science program at Yale: a psychiatrist's first impressions, J. Legal Educ. 11 (1959): 99

Kay, A. C., Wheeler, S. C., Bargh, J. A., \& Ross, L. (2004). Material priming: The influence of mundane physical objects on situational construal and competitive behavioural choice. Organizational behaviour and Human Decision Processes 95, 83-96.

Keown, Charles F., Paul Slovic, and Sarah Lichtenstein. "Influence of Information About Side Effects on Perceived Risks of Prescription Drugs." Health marketing quarterly 1.2-3 (1984): 111-123.

Klein, Julie Thompson (1990), Interdisciplinary: History, Theory and Practice, Detroit: Wayne State University Press.

Korobkin, Russell B., and Thomas S. Ulen. "Law and behavioural science: Removing the rationality assumption from law and economics." California law review (2000): 1051-1144.

H.E. Kyburg, Jr. and H.E. Smokler (eds.) (1964). Studies in subjective probability. New York: Wiley.

Laibson, David. 1997. “Golden Eggs and Hyperbolic Discounting.” Quarterly Journal of Economics 112(2):443-77. 
Malecka, M. and Nagatsu, M. (2019) 'How behavioural research has informed consumer law: The many faces of behavioural research' in Hans-W. Micklitz, Anne-Lise Sibony, Fabrizio Esposito (eds.) Research handbook on methods in consumer law: A handbook. Edward Elgar Publishing. Earlier Draft: Please cite the published version.

Latin, Howard A. "Environmental deregulation and consumer decisionmaking under uncertainty." Harv. Envtl. L. Rev. 6 (1982): 187

Latin, Howard. "Good warnings, bad products, and cognitive limitations." Ucla L. Rev. 41 (1993): 1193.

Lawrence M.. Friedman, and Stewart Macaulay. Law and the behavioural Sciences. Bobbs-Merrill, 1969.

Liberman, V., Samuels, S. M., \& Ross, L. (2004). The name of the game: Predictive power of reputations versus situational labels in determining Prisoner's Dilemma game moves. Personality and Social Psychology Bulletin, 30, 1175-1185.

Lichtenstein, S., Slovic, P., 1971. Reversals of preferences between bids and choices in gambling decisions. Journal of Experimental Psychology 89, 46-55.

Lichtenstein, S., Slovic, P., 1973. Response-induced reversals of preference in gambling extended replication in Las-Vegas. Journal of Experimental Psychology 101, 16-20.

Lichtenstein, S., Slovic, P., 2006. The Construction of Preference. Cambridge University Press, Cambridge.

Lisciandra, Chiara (unpublished) "On the Introduction of Social Preferences in behavioural Economics"

Loevinger, Lee. "Jurimetrics: Science and prediction in the field of law." Minn. L. Rev. 46 (1961): 255.

Luce, R. D., \& Raiffa, H. (1957). Games and decisions: Introduction and critical survey. New York: Wiley.

Luth, Hanneke. behavioural economics in consumer policy: The economic analysis of standard terms in consumer contracts revisited. Diss. Erasmus School of Law (ESL), 2010.

Luzak, Joasia. "Online disclosure rules of the Consumer Rights Directive: protecting passive or active consumers?." Journal of European Consumer and Market Law 4.3 (2015): 79-87.Macaulay, Stewart. "Law and the behavioural Sciences: Is There Any There There?." Law \& Policy 6.2 (1984): 149-187.

MacInnis, D. J., \& Folkes, V. S. (2010). The disciplinary status of consumer behaviour: A sociology of science perspective on key controversies. Journal of Consumer Research, 36(6), 899-914.

Martin, Robert, (2014) "The St. Petersburg Paradox", The Stanford Encyclopedia of Philosophy (Summer 2014 Edition), Edward N. Zalta (ed.), URL = <https://plato.stanford.edu/archives/sum2014/entries/paradox-stpetersburg/>

Mason, Joseph Barry, and Samuel H. Himes. "An exploratory behavioural and socio-economic profile of consumer action about dissatisfaction with selected household appliances." Journal of Consumer Affairs 7.2 (1973): 121-127.

McWilliams, Spencer A. "Psychology, History of (Twentieth Century)." Wright, James D. International Encyclopedia of the Social \& behavioural Sciences (2015): 412-417.

Miller, D. (2001). “Introduction” In Miller, D. (ed.), Consumption: critical concepts in the social sciences. Vol. III. Disciplinary approaches to consumption. London and New York: Routledge. 
Malecka, M. and Nagatsu, M. (2019) 'How behavioural research has informed consumer law: The many faces of behavioural research' in Hans-W. Micklitz, Anne-Lise Sibony, Fabrizio Esposito (eds.) Research handbook on methods in consumer law: A handbook. Edward Elgar Publishing. Earlier Draft: Please cite the published version.

Miller, James G. "Toward a general theory for the behavioural sciences." American Psychologist 10.9 (1955): 513.

Miller, G.A. (1956) The Magical Number Seven, Plus or Minus Two: Some Limits on Our Capacity for Processing Information, 63 PSYCH. REv. 81, 81-97

Mitchell, J. (1999). Measurement in psychology: A critical history of a methodological concept. Cambridge: Cambridge University Press.

Molm, Linda D., et al. "The Legitimacy of behavioural Theory as a Sociological Perspective [with Comments and Rejoinder]." The American Sociologist (1981): 153-184.

Morgan, James N. "Multiple motives, group decisions, uncertainty, ignorance, and confusion: A realistic economics of the consumer requires some psychology." The American Economic Review (1978): 58-63.

Mosteller, F., Nogee, P., 1951. An experimental measurement of utility. Journal of Political Economy 59 (5), 371-404.

Mäki, U. 2016. Interdisciplinarity. What? Why? How? European Journal of Philosophy of Science 6: 327-342.

Nisbett, R. E., \& Ross, L. (1980). Human inference: Strategies and shortcomings of social judgment. Englewood Cliffs, NJ: Prentice-Hall.

Nisbett, Richard E., and Timothy D. Wilson. (1977). "Telling more than we can know: Verbal reports on mental processes." Psychological review 84(3): 231.

Phelps, Edmund S., and Robert, A. Pollak. 1968. "On Second-Best National Saving and Game-Equilibrium Growth.” Review of Economics Studies 35(2):185-199.

Phillips, Lawrence D., and Ward Edwards. "Conservatism in a simple probability inference task." Journal of experimental psychology 72.3 (1966): 346.

Reber, Arthur S. "Oxford psychology series, No. 19. Implicit learning and tacit knowledge: An essay on the cognitive unconscious." (1993).

Ross, D., 2014. Philosophy of Economics. Palgrave Macmillan, New York.

Ross, L., \& Nisbett, R. E. (1991). The person and the situation: Perspectives of social psychology. New York: McGraw-Hill.

Ross, L., Lepper, M., \& Ward, A. (2010). History of social psychology: Insights, challenges, and contributions to theory and application. In Susan T. Fiske, Daniel T. Gilbert, and Gardner Lindzey (eds.) Handbook of social psychology 3-50. John Wiley \& Sons, Inc.

Samuelson, P.A., 1937. A note on measurement of utility. The Review of Economic Studies 4 (2), 155-161.

Samuelson, P. A. 1948. Consumption theory in terms of revealed preference, Economica, vol. 15, 243-53

Samuelson, P. A. 1950. The problem of integrability in utility theory, Economica, vol. 17, 355-85

Savage, L.J., 1954. The Foundations of Statistics. Wiley, New York.

Schwartz, Richard D. "The Law and behavioural Science Program at Yale: A Sociologist's Account of Some Experiences." J. Legal Educ. 12 (1959): 91. 
Malecka, M. and Nagatsu, M. (2019) 'How behavioural research has informed consumer law: The many faces of behavioural research' in Hans-W. Micklitz, Anne-Lise Sibony, Fabrizio Esposito (eds.) Research handbook on methods in consumer law: A handbook. Edward Elgar Publishing. Earlier Draft: Please cite the published version.

Schwartz, Alan, and Louis L. Wilde. "Imperfect information in markets for contract terms: The examples of warranties and security interests." Virginia Law Review (1983): 1387-1485.

Shaw, Eric H. and D. G. Brian Jones (2005), "A History of Schools of Marketing Thought," Marketing Theory, 5 (3), 239-81.

Simonson, I., Carmon, Z., Dhar, R., Drolet, A., \& Nowlis, S. M. (2001). Consumer research: In search of identity. Annual Review of Psychology, 52(1): 249-275.

Symposium "Law And Society \& Law And Economics: Common Ground, Irreconcilable Differences, New Directions: On Beyond Interest: Rational, Normative And Cognitive Perspectives In The Social Scientific Study Of Law." Wis. L. Rev. 1997 Sibony, A.-L. \& Helleringer, G. (2015). Consumer law and behavioural sciences. In A. Alemanno, A. \& A.-L. Sibony (Eds.), Nudge and the law (209-233). Oxford: Hart publishing.

Silber, Norman I. "Observing Reasonable Consumers: Cognitive Psychology, Consumer behaviour and Consumer Law." Loy. Consumer L. Rep. 2 (1989): 69.

Simon, Herbert A. "Models of man; social and rational." (1957).

Simon, Herbert A. "Rationality as process and as product of thought." The American economic review (1978): 1-16.

Smits, Jan. "Full Harmonization of Consumer Law-A Critique of the Draft Directive on Consumer Rights." Eur. Rev. Private L. 18 (2010): 5.

Smith, Edward, Cognitive History: History, in: Wright, James D. International Encyclopedia of the Social \& behavioural Sciences (2015):

Strotz, Robert H. 1956. "Myopia and Inconsistency in Dynamic Utility Maximization." Review of Economic Studies 23(3):165-80.

Sunstein, Cass R., and Richard H. Thaler. "Libertarian paternalism is not an oxymoron." The University of Chicago Law Review (2003): 1159-1202.

Thaler, R., 1980. Toward a positive theory of consumer choice. Journal of Economic behaviour \& Organization 1 (1), 39-60.

Thaler, R., 1981. Some empirical evidence on dynamic inconsistency. Economics Letters 8 (3), 201-207.

Thaler, Richard H. and Sunstein, Cass R. (2008) Nudge: Improving Decisions About Health, Wealth, and Happiness. New Haven, CT: Yale University Press.

Triandis, Harry C. "Subjective culture and interpersonal relations across cultures." Annals of the New York Academy of Sciences 285.1 (1977): 418-434.

Tversky, A., Kahneman, D., 1971. Belief in the law of small numbers. Psychological Bulletin 76 (2), 105-110.

Tversky, A., Kahneman, D., 1974. Judgement under uncertainty: heuristics and biases. Science 185, 1124-1131.

Tversky, A., Kahneman, D., 1981. The framing of decision and the psychology of choice. Science 211, 453-458. 
Malecka, M. and Nagatsu, M. (2019) 'How behavioural research has informed consumer law: The many faces of behavioural research' in Hans-W. Micklitz, Anne-Lise Sibony, Fabrizio Esposito (eds.) Research handbook on methods in consumer law: A handbook. Edward Elgar Publishing. Earlier Draft: Please cite the published version.

Tversky, Amos, and Daniel Kahneman. "Judgment under uncertainty: Heuristics and biases." Utility, probability, and human decision making. Springer Netherlands, 1975. 141-162.

Tversky, A., Kahneman, D., 1986. Rational choice and the framing of decisions. The Journal of Business 59 (4), S251-S278.

Tversky, A., Kahneman, D., 1992. Advances in prospect theory: cumulative representation of utility. Journal of Risk and Uncertainty 5, 297-323.

von Neumann, J., Morgenstern, O., 1944. Theory of Games and Economic behaviour, Princeton University Press, Princeton, NJ.

Wason PC and Evans JSBT (1975). Dual processes in reasoning? Cognition, 3, 141-154.

Weiss, Howard M., and Russell Cropanzano. "Affective events theory: A theoretical discussion of the structure, causes and consequences of affective experiences at work." (1996). 